University of Nebraska - Lincoln

DigitalCommons@University of Nebraska - Lincoln

\title{
Loess sedimentation in Tibet: provenance, processes, and link with Quaternary glaciations
}

Jimin Sun

Institute of Geology and Geophysics

Sheng-Hua Li

University of Hong Kong

Daniel R. Muhs

US Geological Survey, dmuhs@usgs.gov

Bo Li

University of Hong Kong

Follow this and additional works at: https://digitalcommons.unl.edu/usgsstaffpub

Part of the Earth Sciences Commons

Sun, Jimin; Li, Sheng-Hua; Muhs, Daniel R.; and Li, Bo, "Loess sedimentation in Tibet: provenance, processes, and link with Quaternary glaciations" (2007). USGS Staff -- Published Research. 183. https://digitalcommons.unl.edu/usgsstaffpub/183

This Article is brought to you for free and open access by the US Geological Survey at DigitalCommons@University of Nebraska - Lincoln. It has been accepted for inclusion in USGS Staff -- Published Research by an authorized administrator of DigitalCommons@University of Nebraska - Lincoln. 


\title{
Loess sedimentation in Tibet: provenance, processes, and link with Quaternary glaciations
}

\author{
Jimin Sun ${ }^{\mathrm{a}, *}$, Sheng-Hua Li ${ }^{\mathrm{b}}$, Daniel R. Muhs ${ }^{\mathrm{c}}$, Bo Li ${ }^{\mathrm{b}}$ \\ ${ }^{a}$ State Key Laboratory of Lithospheric Evolution, Institute of Geology and Geophysics, Chinese Academy of Sciences, P.O. Box 9825, Beijing 100029, China \\ ${ }^{\mathrm{b}}$ Department of Earth Sciences, The University of Hong Kong, Pokfulam Road, Hong Kong, China \\ ${ }^{\mathrm{c}}$ US Geological Survey, MS 980, Box 25046, Federal Center, Denver, CO 80225, USA
}

Received 25 September 2006; received in revised form 30 April 2007; accepted 14 May 2007

\begin{abstract}
Well-preserved loess deposits are found on the foothills of mountains along the middle reaches of the Yarlung Zangbo River in southern Tibet. Optically stimulated luminescence (OSL) dating is used to determine loess ages by applying the single-aliquot regeneration technique. Geochemical, mineralogical, and granulometric measurements were carried out to allow a comparison between loess from Tibet and the Chinese Loess Plateau. Our results demonstrate that (i) the loess deposits have a basal age of 13-11 ka, suggesting they accumulated after the last deglaciation, (ii) loess in southern Tibet has a "glacial" origin, resulting from eolian sorting of glaciofluvial outwash deposits from braided river channels or alluvial fans by local near-surface winds, and (iii) the present loess in the interior of Tibet has accumulated since the last deglaciation when increased monsoonal circulation provided an increased vegetation cover that was sufficient for trapping eolian silt. The lack of full-glacial loess is either due to minimal vegetation cover or possibly due to the erosion of loess as glaciofluvial outwash during the beginning of each interglacial. Such processes would have been repeated during each glacial-interglacial cycle of the Quaternary.
\end{abstract}

(C) 2007 Elsevier Ltd. All rights reserved.

\section{Introduction}

Loess blankets large (perhaps as much as $10 \%$ ) portions of the world (Pye, 1987). In China, loess not only accumulates in north-central China, where it forms the Loess Plateau, but also occurs on the windward sides of high mountain ranges (e.g., Sun, 2002a; Küster et al., 2006) of northwestern China (Fig. 1a). Since the 1980s, there has been considerable effort devoted to Quaternary climatic reconstructions of the Chinese Loess Plateau (e.g., Heller and Liu, 1984; Liu, 1985; Kukla, 1987). The stratigraphic record of alternating loess deposits and paleosols is interpreted to represent glacial-interglacial cycles (Heller and Liu, 1984; Liu, 1985), in response to orbital forcing (Ding et al., 1994). Recent studies demonstrate that dust deposits on the Loess Plateau are transported by nearsurface winds from the Gobi Desert in Mongolia and China (Sun et al., 2000; Sun, 2002b), whereas dust

\footnotetext{
${ }^{*}$ Corresponding author. Tel.: + 861062007549 ; fax: + 861062032495 .

E-mail address: jmsun@mail.igcas.ac.cn (J. Sun).
}

transported by the high-level westerlies is delivered to the distal north Pacific Ocean (Sun et al., 2001; Sun, 2002b) and possibly even Greenland (e.g., Biscaye et al., 1997). However, the Gobi and other deserts serve only as dust and silt "holding areas;" they are the immediate, but not ultimate sources of the loess particles (Smalley, 1966, 1990; Sun, 2002b). The ultimate source of loess particles for the Loess Plateau is linked to production of a vast amount of clastic, silt-sized material associated with various mountain processes, particularly glacial grinding (Smalley and VitaFinzi, 1968) and frost weathering in the high mountains of Central Asia. These glacial and periglacial sediments are ultimately delivered to piedmont areas of desert basins via outwash from glacial meltwaters (Derbyshire et al., 1998; Sun, 2002b). In this context, eolian deposits on the Loess Plateau are indirectly derived from glacial outwash, similar to loess in Europe and North America.

Compared with the detailed work on the loess-paleosol sequences from the Loess Plateau in China, the dune fields and loess deposits in Tibet have not been well studied. Only a few studies have focused on the loess deposits in different 


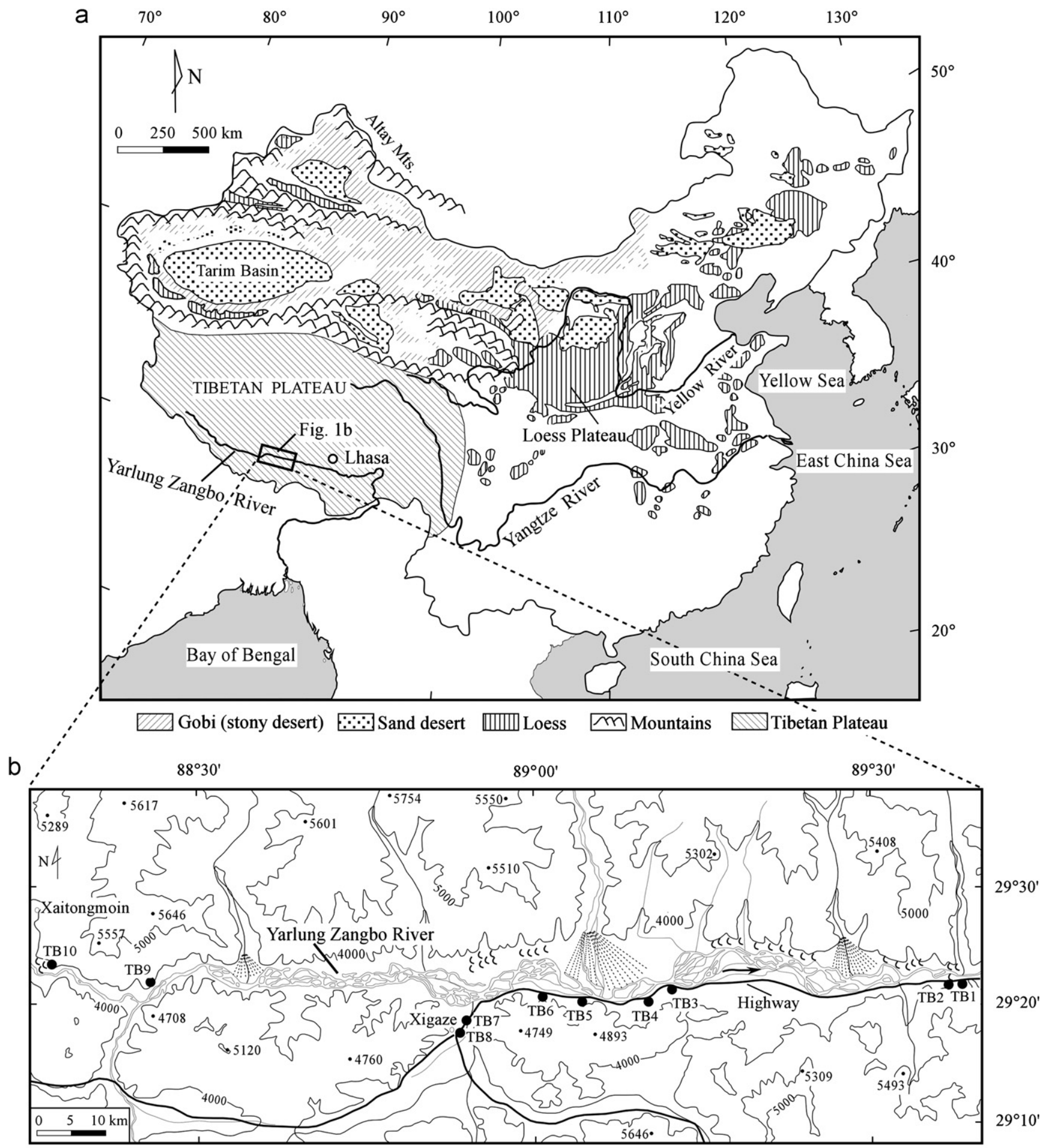

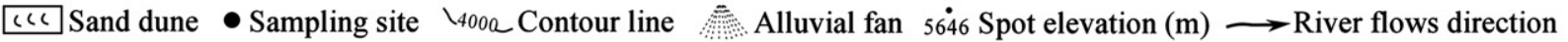

Fig. 1. (a) Schematic map showing mountain ranges, gobi (stony desert), sand desert and loess distribution in China, and (b) enlarged map showing the loess sampling sites, sand dunes, and alluvial fans along the middle reaches of the Yarlung Zangbo River in southern Tibet.

parts of Tibet (Hövermann, 1987; Péwé et al., 1987, 1995; Lehmkuhl, 1997; Lehmkuhl et al., 2000; Rost, 2000; Owen et al., 2006) or in the northern and eastern margins of Tibetan Plateau (Li and Ma, 1996; Fang et al., 2003; Wang et al., 2003; Lu et al., 2004). There have also been studies of modern dust deposition in Tibet (Zhang et al., 2001), as well as studies of past dust deposition recorded in Tibetan ice cores (Thompson et al., 1989, 1997). Nevertheless, many questions about Tibetan loess deposits remain unanswered: 
(1) Although the eolian origin of Chinese loess was proposed first by Richthofen (1882), there has still been much debate on the ultimate source of loess. Two distinct hypotheses of loess generation, a cold or "glacial" source (Smalley, 1966, 1995) and a hot or "desert" source (Obruchev, 1911; Wright, 2001) have existed for many years. A third position (summarized above) views loess as having an ultimate glacial or periglacial source, with an immediate desert source (Sun, 2002b). Because Tibet has an average elevation of above $4500 \mathrm{~m}$, it has many glaciers today and has a rich glacial history (Owen et al., 2005; Lehmkuhl and Owen, 2005). Moraines and other glacial landforms are widespread, and it is therefore an ideal region for examining the processes of "glacial loess" genesis.

(2) An outstanding question concerning the paleoenvironment in Tibet is the timing of the past glaciations. Cosmogenic dating of glacial deposits shows that there is considerable spatial variability in the timing of maximum ice extent in Tibet and that ice advances in the region were not always synchronous with large continental ice sheets (Owen et al., 2005). Both eolian deposits and mountain glaciers occur in Tibet. If the production of loess materials is associated with glacial grinding, then Tibet is a natural laboratory for studying the link between loess accumulation and Quaternary glaciations.

(3) The geochemical composition of the loess on the Loess Plateau has been used to estimate the average composition of the upper continental crust (UCC) (e.g., Taylor et al., 1983; Gallet et al., 1996), but there have been few studies of the composition of Tibetan loess. It is not known whether the geochemical and mineralogical composition of Tibetan loess is similar to that of the Chinese Loess Plateau. Indeed, it is not known whether Tibetan loess is locally derived or the result of long-range transport from a distant source.

To examine these questions, we took two field expeditions to Tibet and carried out geochemical, mineralogical, granulometric and chronological analysis for the loess samples collected there. Together with geomorphological investigations, this paper aims to provide new data on the distribution, age, source area, composition, and genetic mechanisms of loess in Tibet.

\section{Geological setting}

Southern Tibet is situated in a tectonically complex region where the Indian plate collided with the Eurasian plate about $70 \mathrm{Ma}$ (Yin and Harrison, 2000). The region consists of a series of east-west-trending structural blocks or terranes (Aitchison et al., 2000). In our study area, the structural block is the Lhasa terrane, which consists mainly of continental rocks, including Cretaceous-Tertiary granites, Tertiary volcanics, and other rocks (Fig. 2). The Yarlung Zangbo River is adjacent to a major thrust fault that separates the Lhasa terrane from the next structural block to the south, the Xigaze terrane. This unit consists of volcaniclastic sandstones and marls. Continuing south of the Xigaze terrane are the Tethyan-Himalayan sequences, which include ophiolites (Dubois-Côté et al., 2005), mélange (Dupuis et al., 2005) and flysch rocks.

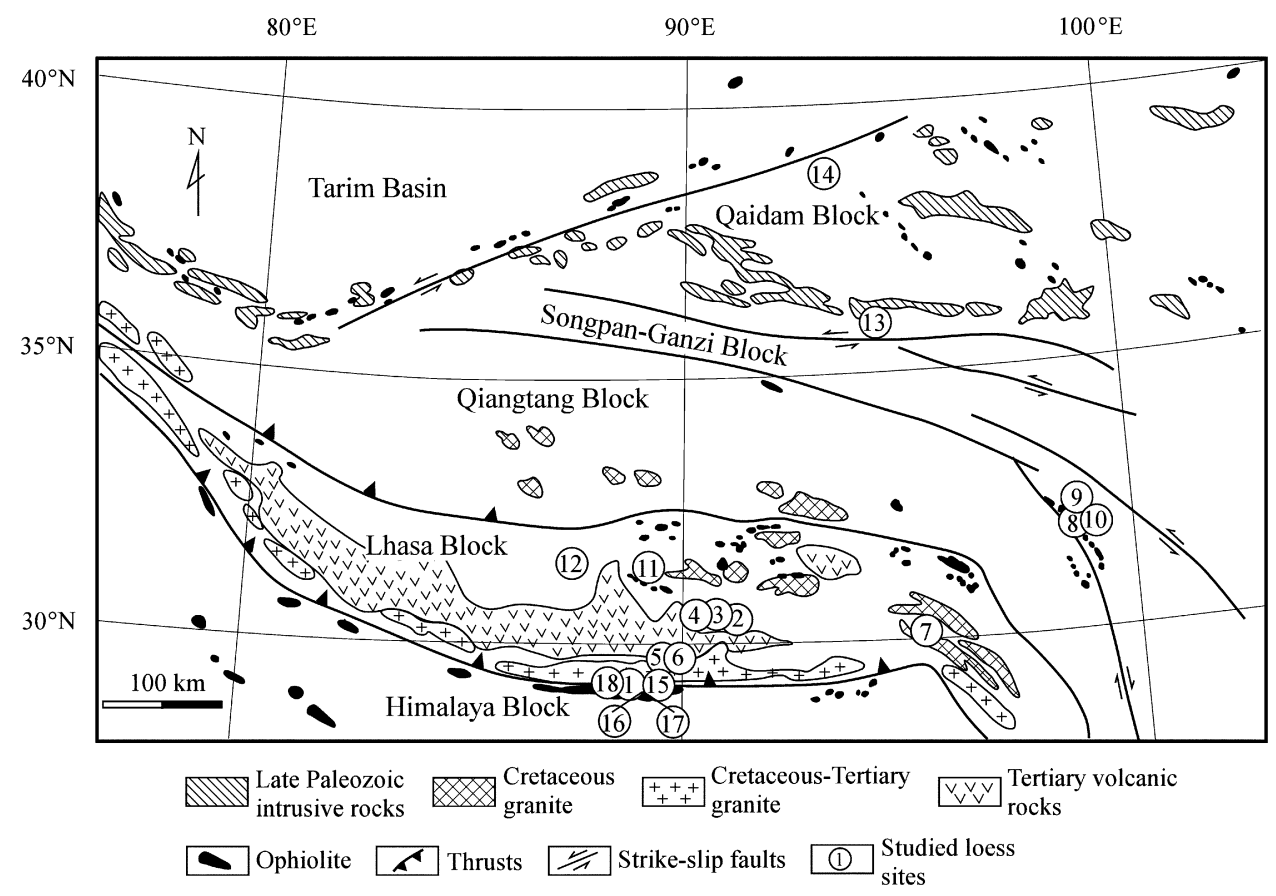

Fig. 2. Geological map showing the tectonic units and main rock types in Tibet as well as the locations of previous studied loess sites (modified Sino-UK Geological Expedition Team, 1990). 

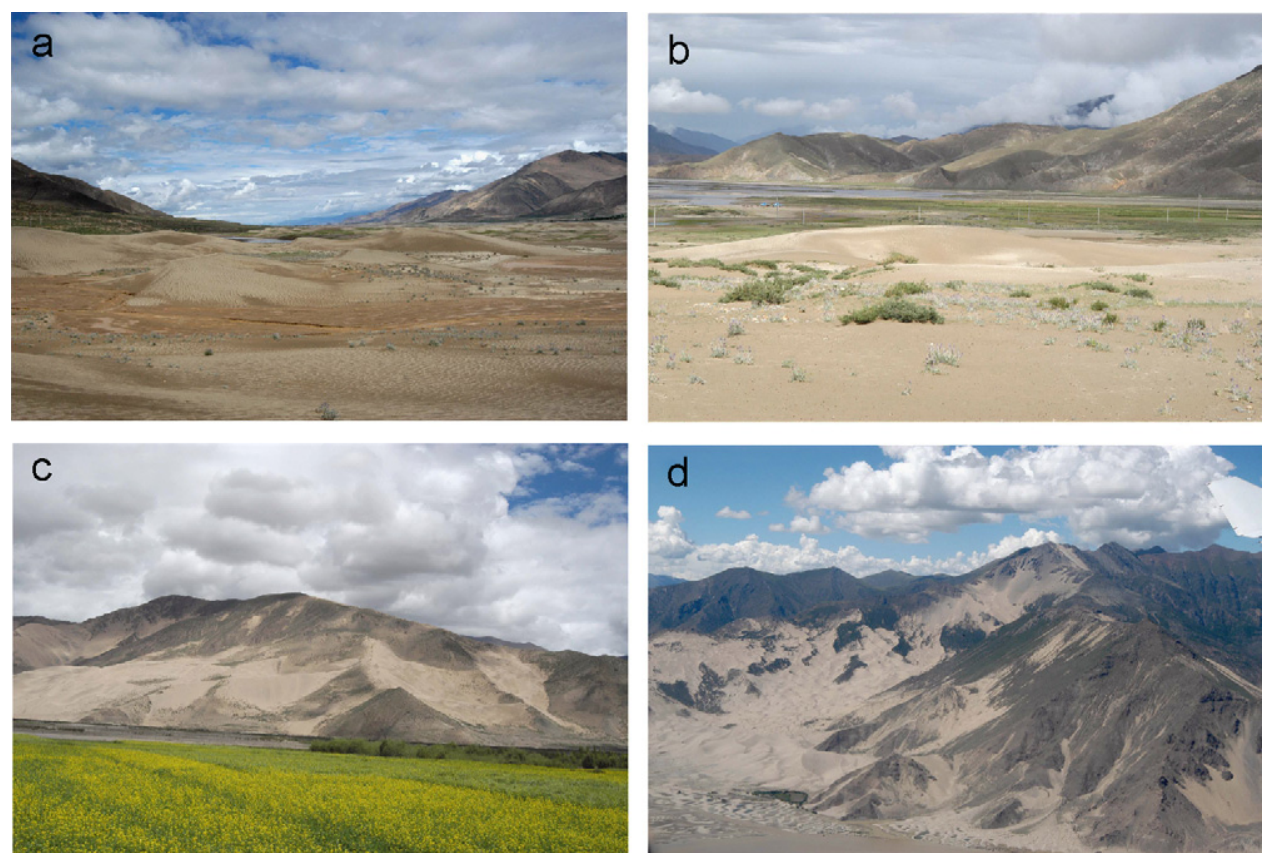

Fig. 3. Photos showing the shifting sand dunes ( $a$ and $b$ ) and sand sheets ( $c$ and $d$ ) in the river valley studied. Note that eolian sand is blowing onto the windward slope of the mountains by the southwesterly winds, nearly reaching the peak of the mountain with an elevation of about $5300 \mathrm{~m}$ above sea level.

We studied eolian deposits in the wide valley that characterizes the middle reaches of the Yarlung Zangbo River (Fig. 1b), where sand dunes and loess deposits are widespread. The Yarlung Zangbo River originates in the northern Himalayas, flows eastward, becomes the westflowing Brahmaputra River in India, joins the southflowing Ganges in Bangladesh, and ultimately empties into the Bay of Bengal in the Indian Ocean. The width of the river valley in the study area varies from 2 to $8 \mathrm{~km}$. Mountains on the northern side of the river have elevations reaching 5500-6000 m; mountains on the southern side of the valley have elevations of $5000-5500 \mathrm{~m}$. Sand dunes within the valley are dominated by barchan and transverse forms (Figs. 3a,b) with heights of 3-8 m. Climbing sand dunes and sand sheets are widespread on the windward slopes of the mountains, especially along the northern side of the Yarlung Zangbo River (Figs. 3c,d; see also Péwé et al., 1995, Fig. 16). The climbing dunes can reach elevations up to $5300 \mathrm{~m}$, and are undoubtedly among the highestelevation eolian sands in the world. These landforms closely resemble the climbing dunes or "sand ramps" that are common in the central and eastern Mojave Desert of southern California, USA. The dominant wind direction in the Yarlung Zangbo River valley is from the west or southwest. This wind direction can be recognized from the orientation of dunes and the asymmetric distributions of the high-elevation sand sheets in the river valley.

Loess is found at lower elevations. Within the study area, there are two river terraces along the Yarlung Zangbo River. A low terrace (informally named "T1") is situated $\sim 3-5 \mathrm{~m}$ above the present valley floor, and is covered by alluvial fan deposits. However, a higher $(\sim 15-20 \mathrm{~m}$ above the valley floor) terrace ("T2") is found above T1 and is mantled with loess. The loess deposits are a light-yellowish color, homogeneous, porous, and show no signs of bedding or reworking. Loess mantles many different landforms, including the high river terraces (Figs. 4a,b), but also low hills and mountain slopes (Figs. 4c,d). The thickest loess beds are found on the high river terrace (T2) with thicknesses ranging from 2 to $10 \mathrm{~m}$. Péwé et al. (1995) described loess deposits as thick as $\sim 15 \mathrm{~m}$ near Xigaze, but interpreted much of this as re-transported loess. In contrast, the loess blanket on the mountain slopes is usually less than $2 \mathrm{~m}$ thick. Still farther north, southeast of Nyainqentanglha Shan and northwest of the city of Lhasa, loess is also present, but is less than $\sim 1$ m thick (Lehmkuhl et al., 2000). Within the study area, loess occurs mainly between 3800 and $4300 \mathrm{~m}$ above sea level, where the steppe vegetation, dominated by Sopora moorcroftiana, Orinus thoroldii, Pennisetum flaccidum, Oxytropis sericopetala, Astragalus strictus, and Stellera chamaejasme, has effectively trapped the eolian silt.

\section{Materials and methods}

Four loess samples were collected for optically stimulated luminescence (OSL) dating from four loess-covered terraces (Fig. 5). Ten bulk loess samples were collected from ten sites along the course of the Yarlung Zangbo River valley (see Fig. $1 \mathrm{~b}$ for localities). In order to compare the composition of Tibetan loess with that of the extensive loess in north-central China, we also collected ten bulk samples from different sites on the Chinese Loess Plateau. Samples for OSL dating were measured in the Luminescence Dating Laboratory in The University of Hong Kong using an automated Risø TL/OSL reader, described by 

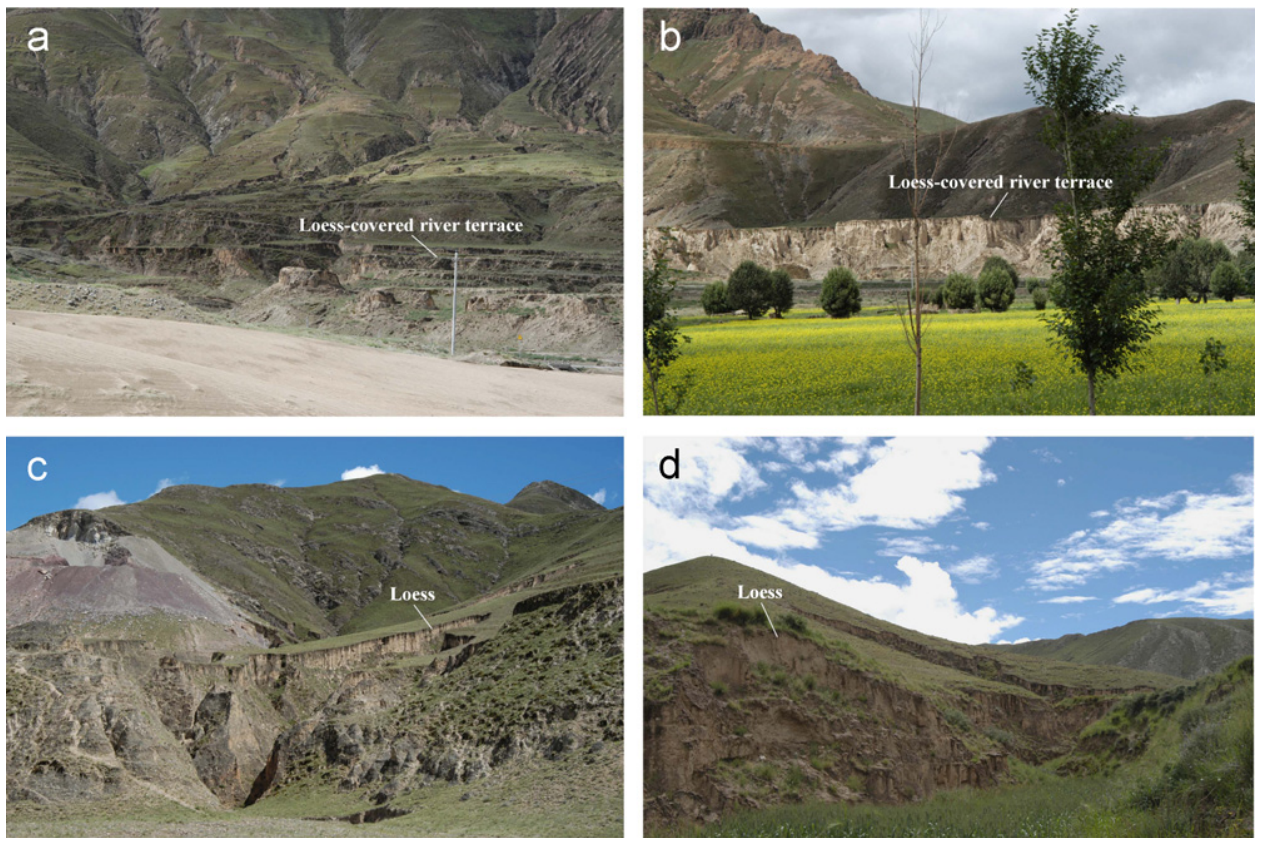

Fig. 4. Photos showing the loess-covered river terraces (a and b), thin loess deposits at the foothills of mountains (c), and loess-mantle blanketing mountain hills (d) in the region studied.
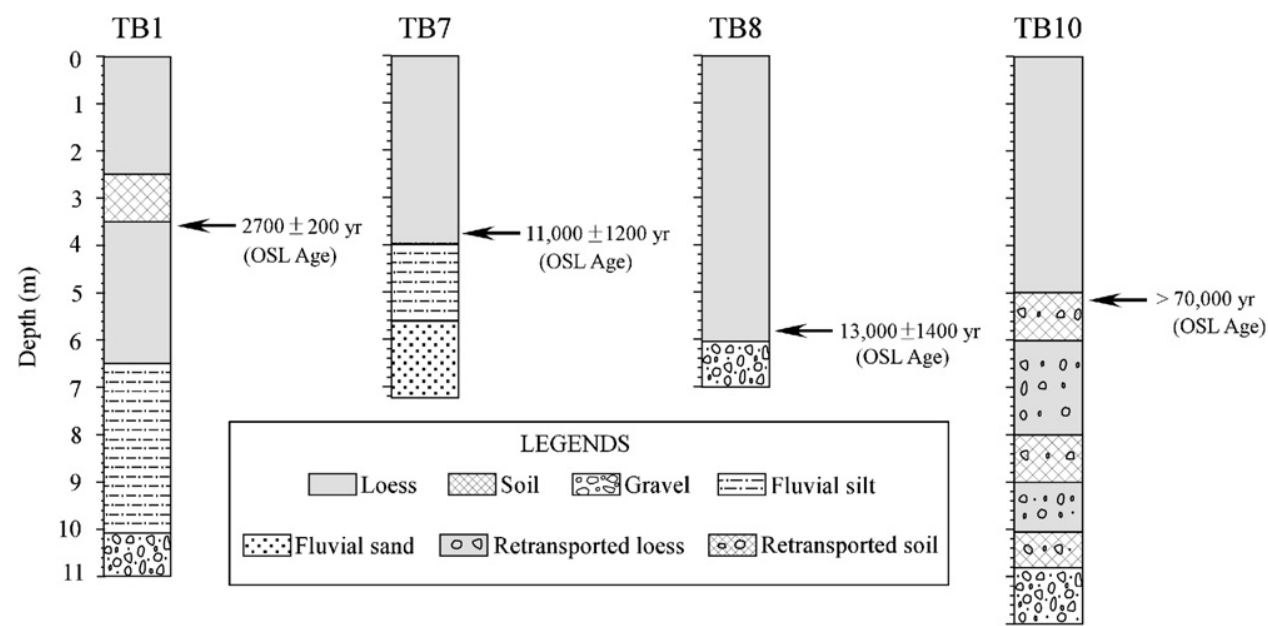

Fig. 5. Selected profiles show the lithology of the loess-covered river terraces and the sampling positions of OSL dating samples.

Markey et al. (1997). Quartz grains of $100-130 \mu \mathrm{m}$ were prepared following procedures of sieving, heavy liquid separation and HF etching in subdued red safe-light conditions (Aitken, 1998). The equivalent doses (De) were determined by the single-aliquot regeneration (SAR) protocol (Murray and Wintle, 2000). The environmental dose rate (Table 1) was measured using a variety of techniques. Thick-source alpha counting was used to measure contributions from the $\mathrm{U}$ and $\mathrm{Th}$ decay chains (Aitken, 1985). The K content was measured by flame photometry. Water content was calculated from the sample weights before and after oven-drying at $105^{\circ} \mathrm{C}$ for $24 \mathrm{~h}$. The cosmic ray contribution to the dose rate was calculated from the burial depth and the altitude of the samples (Prescott and Hutton, 1994).
Trace-element concentrations (including the rare earth elements, REE) were measured by using ICP-MS (ELEMENT, Finnigan MAT) in the Institute of Geology and Geophysics, Chinese Academy of Sciences, following the method described in detail by Gallet et al. (1996). We estimate that uncertainties in the analysis are less than $5 \%$. Mineralogical analyses were performed using an X-ray diffractometer (DMAX 2400). We estimate the analytical uncertainties for mineralogy are about $10 \%$.

Particle size measurements of all samples were measured on bulk samples using a computer-operated SALD-3001 laser microsizer. Ultrasonic pretreatment involving the addition of $20 \%\left(\mathrm{NaPO}_{3}\right)_{6}$ solution was used to disperse the samples before particle measurement. Analysis of 20 replicates showed a precision of $5 \%$ for this procedure. 
Table 1

Single-aliquot-quartz equivalent does, does rate and OSL ages for loess samples from Tibet

\begin{tabular}{|c|c|c|c|c|c|c|c|c|c|}
\hline Sample & $\begin{array}{l}\text { Depth } \\
(\mathrm{m})\end{array}$ & $\begin{array}{l}\text { Alpha } \\
\text { counting } \\
\text { rate }^{\mathrm{a}}\end{array}$ & $\begin{array}{l}\mathrm{K} \text { content } \\
(\%)\end{array}$ & $\begin{array}{l}\text { Water } \\
\text { content }^{\mathrm{b}} \\
(\%)\end{array}$ & $\begin{array}{l}\text { Cosmic } \\
\operatorname{ray}^{\mathrm{c}}(\mathrm{Gy} / \\
\left.10^{3} \mathrm{yr}\right)\end{array}$ & $\begin{array}{l}\text { Number of } \\
\text { aliquots }\end{array}$ & $\begin{array}{l}\text { Equivalent } \\
\text { dose (Gy) }\end{array}$ & $\begin{array}{l}\text { Dose rate } \\
\left(\mathrm{Gy} / 10^{3} \mathrm{yr}\right)\end{array}$ & OSL age (yr) \\
\hline TB1 & 3.5 & 16.55 & 2.17 & 5.1 & 0.46 & 20 & $13.7 \pm 1.6$ & $5.12 \pm 0.31$ & $2700 \pm 200$ \\
\hline TB7 & 3.8 & 14.14 & 1.56 & 4.8 & 0.46 & 27 & $46.8 \pm 7.7$ & $4.21 \pm 0.32$ & $11,000 \pm 1200$ \\
\hline TB8 & 5.8 & 15.8 & 2.11 & 5.2 & 0.46 & 19 & $64.2 \pm 6.0$ & $4.95 \pm 0.30$ & $13,000 \pm 1400$ \\
\hline TB10 & 5.2 & 15.14 & 2.10 & 4.9 & 0.46 & 11 & $>300 \mathrm{~Gy}$ & $4.19 \pm 0.22$ & $>70,000$ \\
\hline
\end{tabular}

${ }^{\mathrm{a}}$ The alpha counting rate is for a $42-\mathrm{mm}$-diameter $\mathrm{ZnS}$ screen and is given in units of counts per kilosecond.

${ }^{\mathrm{b}}$ The error for the water content is estimated at $\pm 20 \%$.

${ }^{\mathrm{c}}$ The error for the cosmic rays dose rate is estimated at $\pm 0.02 \mathrm{~Gy} / 10^{3} \mathrm{yr}$.

Table 2

Loess ages in Tibet (see Fig. 2 for site locations)

\begin{tabular}{|c|c|c|c|c|c|c|}
\hline Site & Latitude & Longitude & Altitude (m) & Age (yr) & Dating methods & Data source \\
\hline \multirow[t]{2}{*}{1} & $29^{\circ} 13^{\prime}$ & $88^{\circ} 57^{\prime}$ & 3950 & $2010 \pm 85$ & ${ }^{14} \mathrm{C}$ & Péwé et al. (1995) \\
\hline & $29^{\circ} 13^{\prime}$ & $88^{\circ} 57^{\prime}$ & 3950 & $3645 \pm 110$ & ${ }^{14} \mathrm{C}$ & Péwé et al. (1995) \\
\hline 2 & $30^{\circ} 34^{\prime}$ & $91^{\circ} 07^{\prime}$ & 4500 & $9700 \pm 2000$ & OSL & Lehmkuhl et al. (2000) \\
\hline 3 & $30^{\circ} 25^{\prime}$ & $90^{\circ} 49^{\prime}$ & 4680 & $9200 \pm 2100$ & OSL & Lehmkuhl et al. (2000) \\
\hline 4 & $30^{\circ} 26^{\prime}$ & $90^{\circ} 48^{\prime}$ & 4620 & $10,500 \pm 2200$ & OSL & Lehmkuhl et al. (2000) \\
\hline 5 & $29^{\circ} 44^{\prime}$ & $89^{\circ} 49^{\prime}$ & 4571 & $8800 \pm 3900$ & OSL & Lehmkuhl et al. (2000) \\
\hline 6 & $29^{\circ} 46^{\prime}$ & $89^{\circ} 51^{\prime}$ & 4835 & $7800 \pm 1200$ & OSL & Lehmkuhl et al. (2000) \\
\hline 7 & $30^{\circ} 08^{\prime}$ & $95^{\circ} 30^{\prime}$ & 3070 & $25,500 \pm 4000$ & OSL & Lehmkuhl et al. (2000) \\
\hline 8 & $31^{\circ} 57^{\prime}$ & $98^{\circ} 48^{\prime}$ & 4220 & $8100 \pm 2100$ & OSL & Lehmkuhl et al. (2000) \\
\hline 9 & $32^{\circ} 07^{\prime}$ & $98^{\circ} 52^{\prime}$ & 4010 & $8900 \pm 1100$ & OSL & Lehmkuhl et al. (2000) \\
\hline 10 & $31^{\circ} 59^{\prime}$ & $99^{\circ} 05^{\prime}$ & 4150 & $3100 \pm 500$ & OSL & Lehmkuhl et al. (2000) \\
\hline 11 & $31^{\circ} 29^{\prime}$ & $89^{\circ} 13^{\prime}$ & 4646 & $7000 \pm 600$ & $\mathrm{TL}$ & Lehmkuhl et al. (2000) \\
\hline 12 & $31^{\circ} 44^{\prime}$ & $87^{\circ} 32^{\prime}$ & 4715 & $3500 \pm 300$ & $\mathrm{TL}$ & Lehmkuhl et al. (2000) \\
\hline 13 & $35^{\circ} 55^{\prime}$ & $94^{\circ} 40^{\prime}$ & 3631 & $8,600 \pm 700$ & OSL & Owen et al. (2006) \\
\hline 14 & $38^{\circ} 51^{\prime}$ & $93^{\circ} 25^{\prime}$ & 2782 & $14,900 \pm 1500$ & OSL & Owen et al. (2006) \\
\hline 15 & $29^{\circ} 19^{\prime}$ & $89^{\circ} 33^{\prime}$ & 3800 & $2700 \pm 200$ & OSL & This paper \\
\hline 16 & $29^{\circ} 19^{\prime}$ & $88^{\circ} 55^{\prime}$ & 3920 & $11,000 \pm 1200$ & OSL & This paper \\
\hline 17 & $29^{\circ} 16^{\prime}$ & $88^{\circ} 51^{\prime}$ & 3970 & $13,000 \pm 1400$ & OSL & This paper \\
\hline 18 & $29^{\circ} 22^{\prime}$ & $88^{\circ} 16^{\prime}$ & 3950 & $>70,000$ & OSL & This paper \\
\hline
\end{tabular}

\section{Results}

\subsection{Age of the loess}

There have been only a few age determinations for loess in Tibet (Table 2). Péwé et al. (1995) reported radiocarbon ages of $\sim 2000-3600{ }^{14} \mathrm{C}$ yr BP for gastropod shells from the upper part of an $\sim 15$-m-thick loess section near Xigaze, but questioned these ages, at least in part because they thought that the loess was late Pleistocene. Lehmkuhl et al. (2000) reported OSL and radiocarbon ages of thin $(<1 \mathrm{~m})$ loess sections between the mountains of Nyainqentanglha Shan and the city of Lhasa. Their results indicate that loess deposition there began in the early Holocene, around 8000-10,000 yr ago. Buried soils within the loess gave radiocarbon ages of $\sim 2300-4400{ }^{14} \mathrm{C}$ yr BP, suggesting that loess deposition continued intermittently into the late Holocene. Owen et al. (2006) reported loess ages of $14,900 \mathrm{yr}$ and $8600 \mathrm{yr}$ in the Qaidam Basin of the northeastern Tibetan Plateau.
Our new OSL ages are in broad agreement with these earlier studies (Table 2). Among the four OSL ages, three are from typical eolian sediments, whereas one is from re-transported soil (Fig. 5). An OSL age from the top of the lower loess layer at site TB1 is $2700 \pm 200 \mathrm{yr}$, while the other two OSL ages from the bases of the thick loess beds at sites TB7 and TB 8 are $11,000 \pm 1200$ and $13,000 \pm 1400 \mathrm{yr}$, respectively. OSL dating from the top of a re-transported soil layer at Site TB10, which is overlain by a thick loess bed, yields an age of $>70,000 \mathrm{yr}$. However, field observations indicate that there are fluvial sands and small gravel-sized clasts within this soil, suggesting it is composed of re-transported soil and fan sediments. If this interpretation is correct, then it is probable that many of the quartz grains were not well-bleached before deposition and can account for the large uncertainties of the OSL age from this re-transported soil. Péwé et al. (1995) also interpreted many of the sections they examined in this area as consisting of re-transported loess. Because of these uncertainties, we exclude the age from locality TB10 from 
our consideration of loess depositional history. With the remaining OSL analyses that yield confident ages, we infer that loess in the Yarlung Zangbo River valley accumulated primarily after the last deglaciation, beginning around $13,000-11,000 \mathrm{yr}$. The age of $\sim 2700 \mathrm{yr}$ from locality TB1 indicates that loess deposition continued into the late Holocene, similar to the findings of Lehmkuhl et al. (2000).

\subsection{Mineralogy}

The XRD analyses on bulk samples of Tibetan loess indicate that quartz, feldspar, calcite, mica (muscovite or illite), and chlorite (clinochlore) are the most important minerals in all the loess samples, comprising more than $90 \%$ of the total. The other minerals include hornblende, smectite (montmorillonite), and sepiolite. These results are in good agreement with bulk mineralogical and clay mineralogical data for Tibetan loess from the same area reported by Péwé et al. (1995).

A ternary diagram shows the contents of the three most common minerals in loess, quartz, feldspar and calcite (Fig. 6). This plot indicates that Tibetan loess has significantly lower amounts of calcite compared with that of the loess from the Loess Plateau. The mineral compositions of samples from the two regions fall clearly into two distinct fields, suggesting different provenances of loess from Tibet and the Loess Plateau.

\subsection{Chemical composition}

\subsubsection{Rare earth elements (REE)}

Chondrite-normalized REE patterns of loess deposits can yield important clues about their origin. REE patterns of loess from Tibet and the Loess Plateau show three important properties (Fig. 7). First, REE concentrations in Tibetan loess are in general higher than those from the Loess Plateau. We interpret this to be a dilution of the

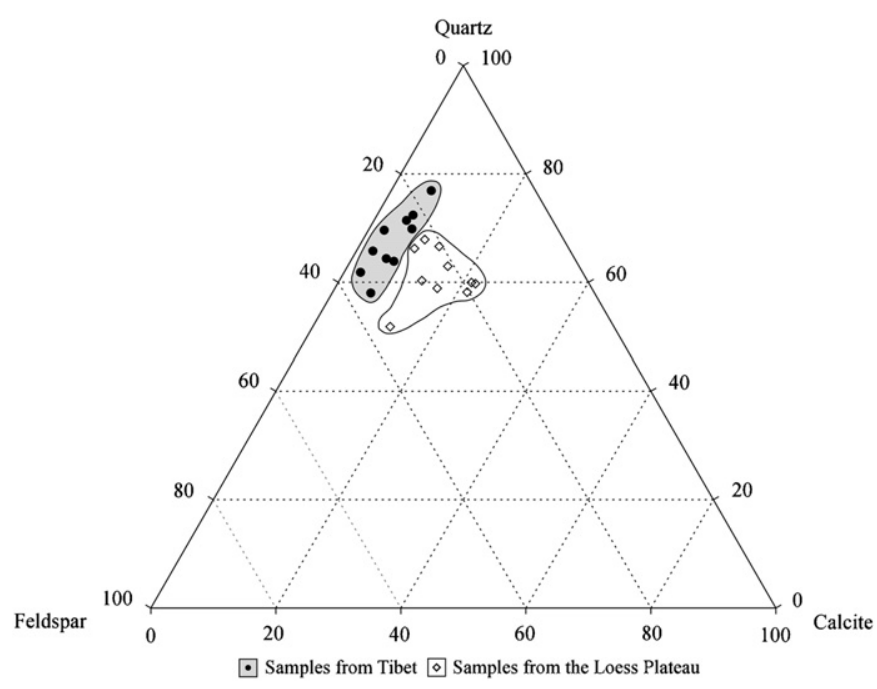

Fig. 6. Ternary diagram comparing relative abundances of quartz, feldspar, and calcite in loess from Tibet and the Loess Plateau.
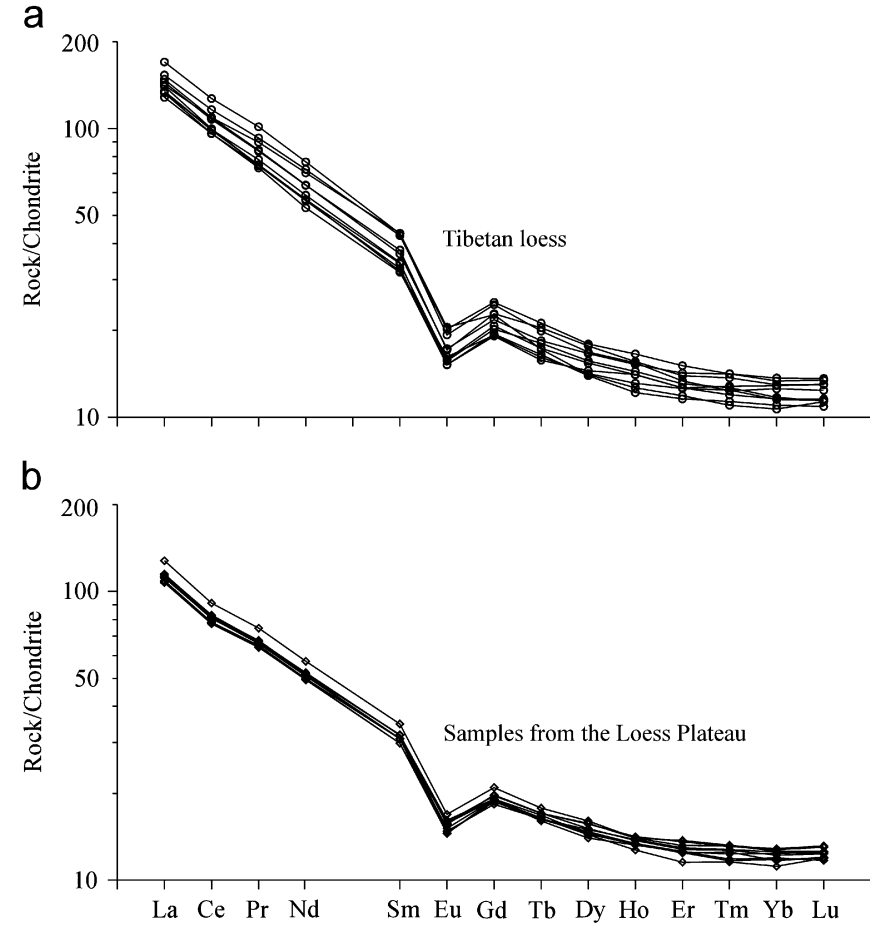

Fig. 7. Chondrite-normalized REE distribution patterns of loess samples from Tibet (a) and the Loess Plateau (b).

REE concentrations in the Loess Plateau samples because of the presence of greater amounts of calcite, as discussed above. Second, all samples are characterized by relatively enriched light rare earth elements (LREE) and a significant negative Eu anomaly, properties that are similar to those of average UCC (Taylor and McLennan, 1985) and previously studied samples from the Loess Plateau (Gallet et al., 1996; Jahn et al., 2001). Third, REE patterns of the Tibetan samples show a significant variation (Fig. 7a), whereas those from the Loess Plateau are nearly constant (Fig. 7b). This difference is attributed to the Tibetan loess samples being derived from the nearby river valleys, with only short transport distances from local winds. In contrast, eolian deposits on the Loess Plateau are derived from the Gobi desert (as well as other deserts) and the dust has been transported by regional-scale winds for hundreds to thousands of kilometers. Thus, deposits on the Loess Plateau are well mixed before deposition.

REE ratios are effective in tracing loess provenance (Liu et al., 1993; Gallet et al., 1996; Sun 2002a,b; Muhs and Budahn, 2006). Among the REE ratios, the ratio of light rare earth elements (LREE) to heavy rare earth elements (HREE) is used to reflect the fractionation of rare earth elements, and high LREE/HREE values indicate depletion of HREE. $\mathrm{Eu} / \mathrm{Eu}^{*}$ is used to indicate the extent of a $\mathrm{Eu}$ anomaly; a negative Eu anomaly occurs when this value less than 1. Tibetan loess has higher values of LREE/ HREE and $\mathrm{Ce} / \mathrm{Yb}$ than the samples from the Loess Plateau (Fig. 8). Both the LREE/HREE vs Eu/Eu* and the $\mathrm{Ce} / \mathrm{Yb}$ vs $\mathrm{Eu} / \mathrm{Yb}$ plots show geographic distinctions, implying their source areas are different. Moreover, samples from 

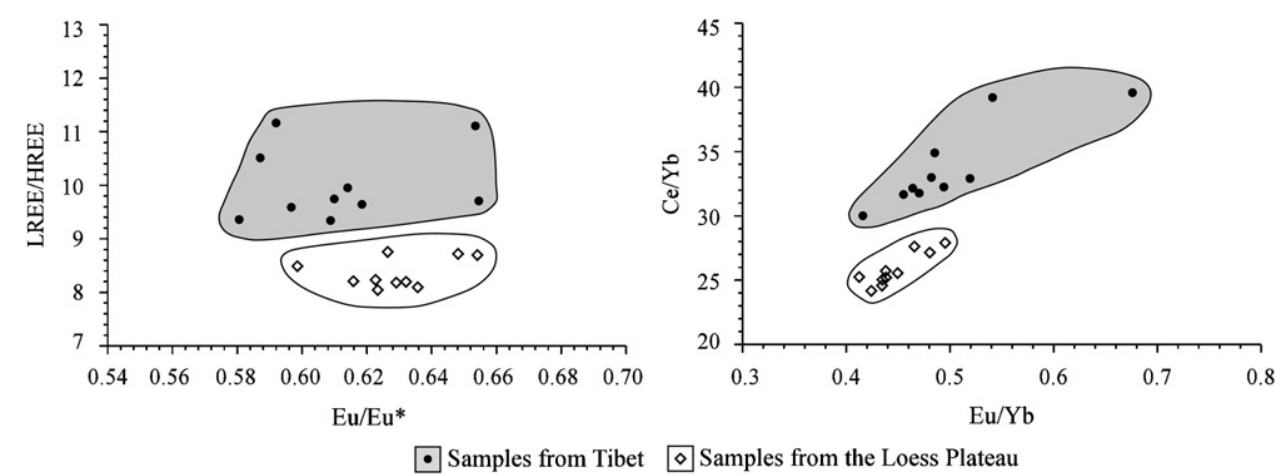

Fig. 8. (LREE/HREE) vs $\mathrm{Eu} / \mathrm{Eu}^{*}$ and $\mathrm{Ce} / \mathrm{Yb}$ vs $\mathrm{Eu} / \mathrm{Yb}$ of loess samples from Tibet and the Loess Plateau.

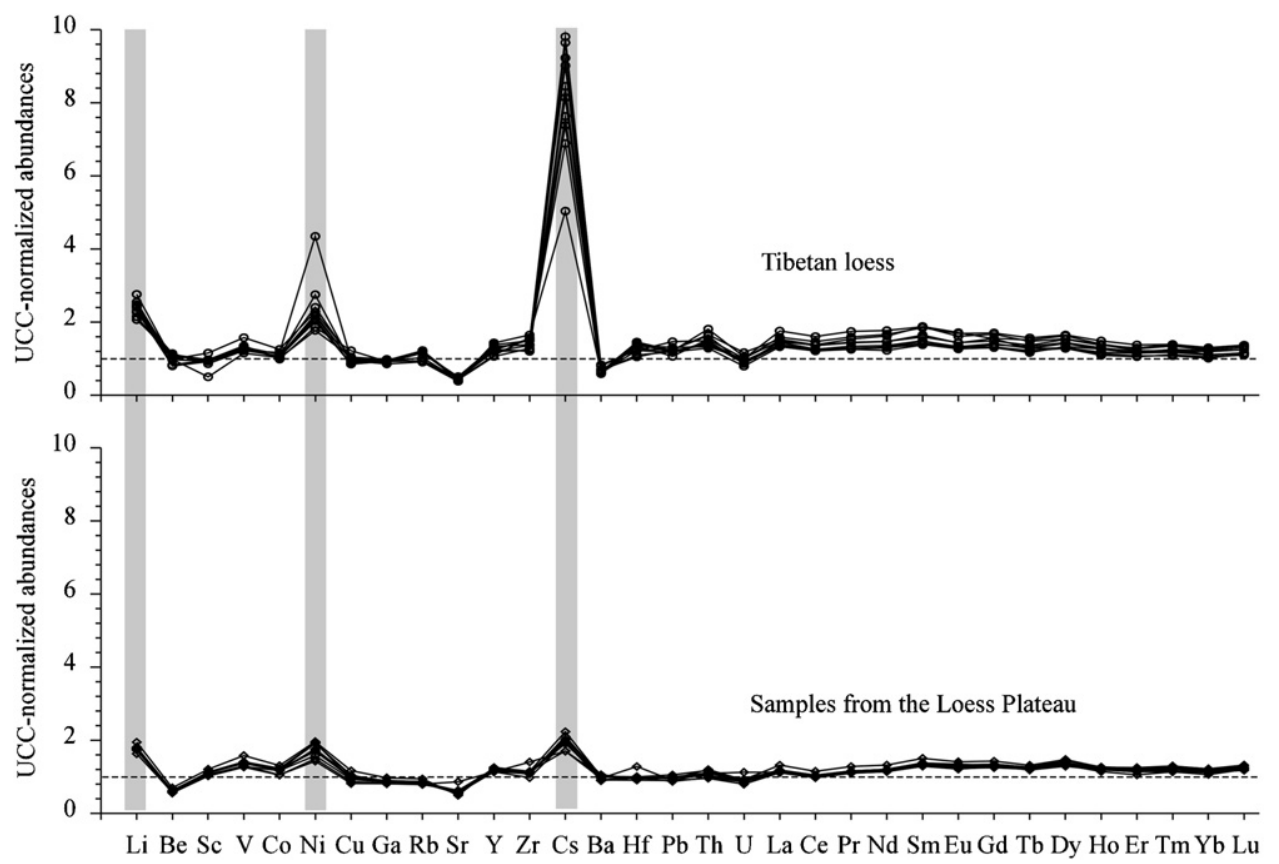

Fig. 9. UCC-normalized spidergrams for the loess samples. The UCC values are from Taylor and McLennan (1985). Shadows indicate the remarkably enriched elements (more than two times of UCC) in loess deposits.

the Loess Plateau show less compositional variability (Fig. 8), implying better mixing during longer distances of transport, consistent with the tightly banded chondritenormalized REE patterns of the loess samples from the Loess Plateau (Fig. 7).

\subsubsection{Other trace elements}

Variations of REE and other trace-element contents are shown in the UCC-normalized spidergrams (Fig. 9). Three main features characterize the trace element abundances. First, the trace-element contents from both Tibet and the Loess Plateau generally resemble the composition of UCC (Taylor et al., 1983). Second, $\mathrm{Li}, \mathrm{Ni}$, and Cs are remarkably enriched in loess compared to UCC (Fig. 9). Finally, enrichment of these three trace elements is significantly higher in Tibetan loess (2-10 times that of UCC) than those from the Loess Plateau (about 2 times that of UCC).

Plots of trace elements and their ratios also provide important information on provenance, as indicated by previous studies of eolian deposits (Liu et al., 1993; Muhs et al., 1996; Sun, 2002a, b). Two elements, $\mathrm{Zr}$ and Hf, are found almost exclusively in zircon, but $\mathrm{Zr} / \mathrm{Hf}$ will vary in zircons derived from different source rocks, depending on their magmatic history (McLennan, 1989). The geochemical behavior of $\mathrm{Sr}$ resembles $\mathrm{Ca}$, and $\mathrm{Sr}$ can replace $\mathrm{Ca}$ in many minerals. In loess deposits of China, $\mathrm{Sr}$ abundance is controlled mainly by carbonate (Jahn et al., 2001). Rb and Cs are mainly hosted in micas and K-feldspar (Heier and Billings, 1970). $\mathrm{Pb}$ is also found mainly in K-feldspar (Beswick, 1973), while $\mathrm{U}$ and $\mathrm{Th}$ are mainly in heavy minerals or sorbed onto clay minerals.

Plots of the selected trace elements and their ratios show that the loess samples taken from Tibet and the Loess Plateau fall into two distinct fields, implying different sources (Fig. 10). Tibetan loess has lower $\mathrm{Sr}$ and, on average, higher $\mathrm{Zr}, \mathrm{Rb}$, and $\mathrm{Cs}$ concentrations. The lower $\mathrm{Sr}$ concentration is mostly associated with the low carbonate content in Tibetan loess, as indicated by XRD 

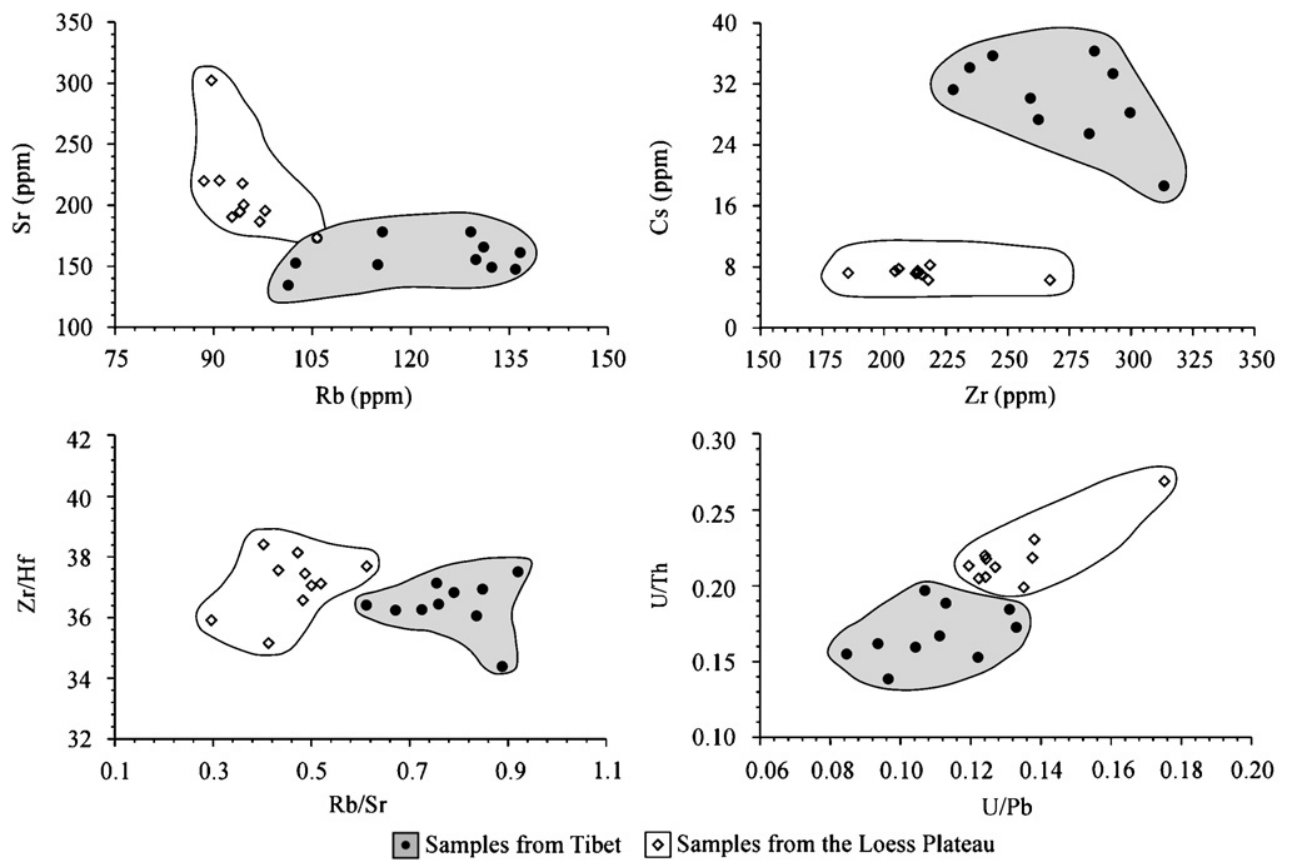

Fig. 10. Plots of $\mathrm{Sr} v \mathrm{Rb}, \mathrm{Cs}$ vs $\mathrm{Zr}, \mathrm{Zr} / \mathrm{Hf}$ vs $\mathrm{Rb} / \mathrm{Sr}$, and $\mathrm{U} / \mathrm{Th}$ vs $\mathrm{U} / \mathrm{Pb}$ for the loess samples from Tibet and the Loess Plateau.

results (Fig. 6). Higher concentrations of $\mathrm{Zr}$ and the alkaline earth elements ( $\mathrm{Rb}$ and $\mathrm{Cs}$ ) in Tibetan loess are mostly related to the higher contents of zircon and $\mathrm{K}$-feldspar, respectively.

\subsubsection{Loess geochemistry and provenance: $S c-T h-L a$ and $\mathrm{Zr}-\mathrm{Sc}-\mathrm{Th}$}

Studies by numerous investigators show that ternary plots of Sc-Th-La and $\mathrm{Zr}-\mathrm{Sc}-\mathrm{Th}$ are sensitive indicators of sediment or sedimentary rock provenance (Taylor and McLennan, 1985; Bhatia and Crook, 1986; Olivarez et al., 1991; Zhang, 2004). Bhatia and Crook (1986) show that sediments derived from a continuum of mafic-to-felsic lithologic-tectonic settings (oceanic island arc, continental island arc, active continental margin, passive continental margin) can be discriminated using relative abundances of $\mathrm{Sc}-\mathrm{Th}-\mathrm{La}$ and $\mathrm{Zr}-\mathrm{Sc}-\mathrm{Th}$. Zhang (2004) applied this approach with success in identifying sources of sedimentary rocks elsewhere in Tibet.

We applied the geochemical approach of Bhatia and Crook (1986) to sediments from four regions to determine if this method might be applicable to loess. Fig. 11 indicates that loess both from Tibet and the Loess Plateau fall into the more felsic geochemical fields, at least compared to New Zealand or Alaskan loess. Nevertheless, Tibetan and Chinese loess have little or no overlap on these plots, indicating different source sediments. Furthermore, Tibetan loess has an even more felsic composition than Chinese loess, suggesting little influence from the more mafic bedrock types in this part of the region. This interpretation can be tested more rigorously with a direct comparison to potential local source rocks.
Loess from New Zealand, probably derived in large part from volcanic materials, shows a mafic composition that falls mostly within the oceanic island arc field (Fig. 11). Loess from Alaska is more felsic than New Zealand loess but more mafic than Tibetan loess, and falls within the continental island arc field, consistent with the ocean-tocontinent collisional-tectonic setting of this part of North America. We conclude from this experiment that $\mathrm{Sc}-\mathrm{Th}-\mathrm{La}$ and $\mathrm{Zr}-\mathrm{Sc}-\mathrm{Th}$ plots can distinguish loesses that are derived from different source materials.

\subsubsection{Comparison of REE geochemistry with local source rocks}

There have been numerous studies of the trace element concentrations of various rocks that make up the tectonic terranes of southern Tibet in the past couple of decades. Although these studies have been conducted primarily for the purpose of understanding tectonic history, they also provide useful data for understanding possible loess sources. Although complete data on abundances of Sc, $\mathrm{Th}, \mathrm{La}$, and $\mathrm{Zr}$ for these rocks are rare, there are numerous data sets that have complete data for the REE.

Many of the rocks in the Lhasa terrane, to the north of the Yarlung Zangbo River (and suture zone) are felsic. We use data on Cretaceous-Tertiary granitic rocks from Debon et al. (1986) and Harrison et al. (2000). Elsewhere on the Lhasa terrane, we use data for granitoid rocks and gneisses found on the southeastern flanks of the Nyainqentanglha Shan from Kapp et al. (2005). The Lhasa terrane also hosts extensive areas of early Tertiary volcanic rocks called the Lanzizong Formation (Fig. 2), but there are few published data on these rocks. We estimated the REE composition of the Lanzizong volcanics from plots in Fig. 7(a) of Ding 

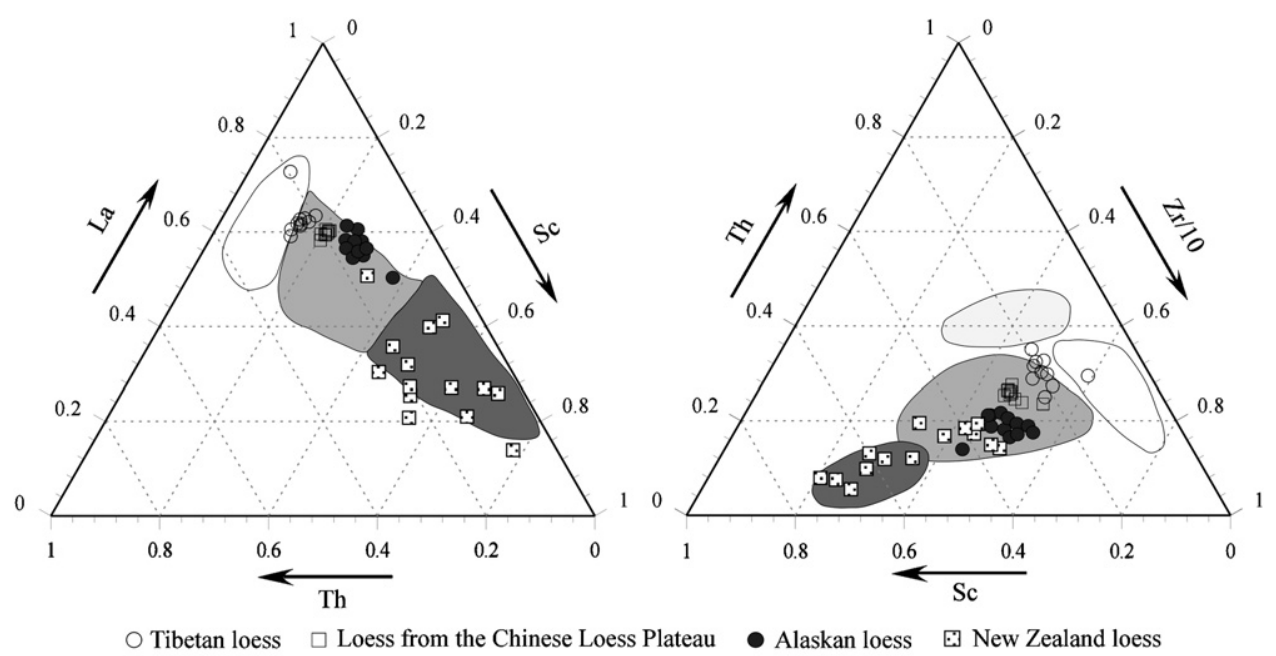

T Tibetan loess $\square$ Loess from the Chinese Loess Plateau - Alaskan loess $\quad \cdot$ N New Zealand loess

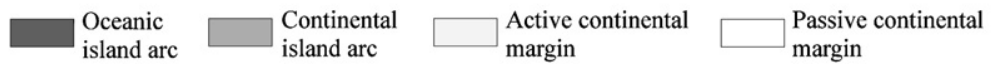

Fig. 11. Ternary plots of Sc-Th-La and Zr/10-Sc-Th showing fields (from Bhatia and Crook (1986) and Zhang (2004)) that link provenance with lithologic-tectonic setting. Also plotted are data for these elements in loess from Alaska (Muhs and Budahn, 2006), New Zealand (Graham et al., 2001), and data in loess from Tibet and China (this study).

et al. (2003). South of the Yarlung Zangbo River (and suture zone), many of the rocks have a more mafic composition. Dubois-Côté et al. (2005) provide data on the geochemistry of ophiolites hosted by the Dazhuqu terrane. The next structural block to the south of the Dazhuqu block is the Bainang terrane, and mafic mélange deposits are hosted by this terrane (Dupuis et al., 2005). Finally, the Bainang terrane is separated from the Indian terrane to the south by a major thrust fault (Aitchison et al., 2000). Dupuis et al. (2005) provide geochemical data for the mafic flysch rocks hosted by the Indian terrane in this area.

We use traditional plots of $\mathrm{Eu} / \mathrm{Eu}^{*}$ (to quantify the amount of the Eu anomaly) vs $\mathrm{La}_{\mathrm{N}} / \mathrm{Yb}_{\mathrm{N}}$ (to quantify the amount of LREE enrichment) and $\mathrm{Eu} / \mathrm{Eu}^{*} \mathrm{vs}^{\mathrm{G}} \mathrm{Gd}_{\mathrm{N}} / \mathrm{Yb}_{\mathrm{N}}$ (to quantify the amount of HREE depletion). Fig. 12 shows that the mafic rocks in terranes to the south of the Yarlung Zangbo River, ophiolites, mélange, and flysch, show only slight negative Eu anomalies and some even have slightly positive $\mathrm{Eu}$ anomalies. In addition, as expected with ultramafic rocks, ophiolites show little LREE enrichment and minimal HREE depletion. Mélange, flysch, and volcanic rocks of the Lanzizong Formation show somewhat more LREE enrichment and HREE depletion than do the ophiolites. The felsic rocks (granitic rocks and gneisses) of the Lhasa terrane, to the north of the Yarlung Zangbo River, show a wide range of $\mathrm{Eu} / \mathrm{Eu}^{*}$ values, as well as quite variable amounts of LREE enrichment and HREE depletion. These observations suggest original derivation from a wide variety of source rocks.

Tibetan loess falls outside of the fields defined by ophiolites, mélange, and flysch, as well as outside the field defined by the Lanzizong volcanics (Fig. 12). However, the loess deposits fall well within the field defined by granitic rocks and close to or within the field defined by Tertiary gneiss of the Lhasa terrane. We hypothesize, therefore, that Tibetan loess most likely is derived from felsic rocks that lay to the north of the Yarlung Zangbo River (and suture zone), from sources in the Lhasa terrane. Because these rocks crop out in the mountains of Nyainqentanglha Shan (Kapp et al., 2005), we infer that glaciers in these high mountains may have played an important role in loess genesis in this part of Tibet.

\subsection{Particle size distribution}

The histograms of grain-size indicate that the Tibetan loess is much coarser than that on the Loess Plateau (Figs. 13a,b). Median sizes of the loess samples from Tibet and the Loess Plateau are 44 and $20 \mu \mathrm{m}$, respectively. Moreover, both the plots of sorting against median size (Fig. 13c) and median size against skewness (Fig. 13d) indicate that the loess samples from Tibet and the Loess Plateau fall into different areas, and the Tibetan loess is poorly sorted and has a higher range of skewness compared with the samples from the Loess Plateau. When examined in more detail, loess from the Chinese Loess Plateau shows a distinct spatial variation in median particle size. A transect from Hongde $(\sim 100 \mathrm{~km}$ south of the Mu Us Desert) to Yangling ( $\sim 300 \mathrm{~km}$ south of the Mu Us Desert), shows that the median particle diameter of loess dating to the last glacial period (L1-1) decreases from $\sim 55$ to $\sim 15 \mu \mathrm{m}$ (Yang and Ding, 2004). Thus, the relatively coarse $(\sim 44 \mu \mathrm{m})$ median particle size of Tibetan loess suggests a source or sources that are not distant and certainly rules out a significant component of long-rangetransported dust. 

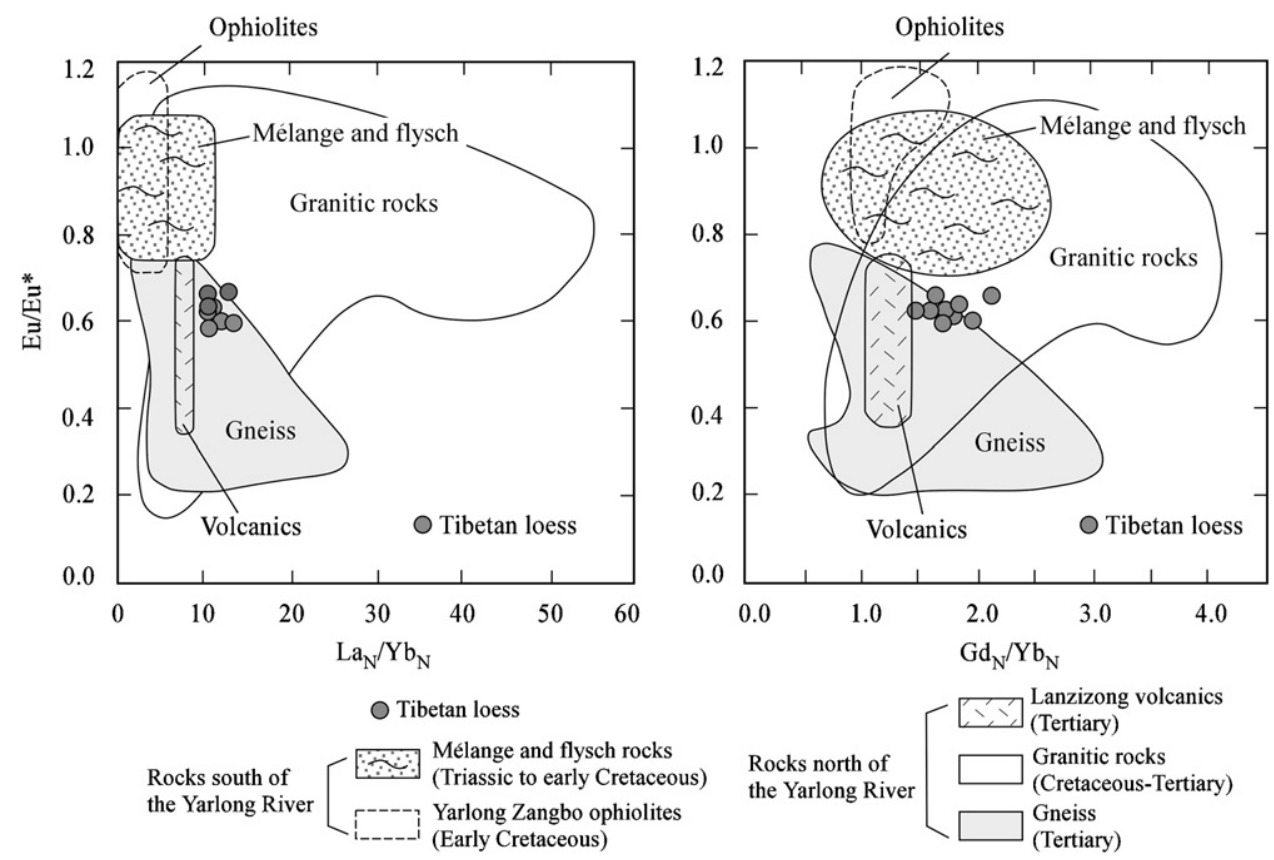

Fig. 12. Plots of $\mathrm{Eu} / \mathrm{Eu}^{*} \mathrm{vs} \mathrm{La}_{\mathrm{N}} / \mathrm{Yb}_{\mathrm{N}}$ and $\mathrm{Eu} / \mathrm{Eu}^{*} \mathrm{vs}_{\mathrm{Gd}} / \mathrm{Yb}_{\mathrm{N}}$ for Tibetan loess and major bedrock types in the middle reaches of the $\mathrm{Yarlung} Z \mathrm{Zangbo}$ River, Tibet. Bedrock data sources are as follows: granitic rocks from Debon et al. (1986), Harrison et al. (2000), and Kapp et al. (2005); gneiss from Kapp et al. (2005); ophiolites from Dubois-Côté et al. (2005); mélange and flysch rocks from Dupuis et al. (2005); Lanzizong volcanics estimated graphically from Fig. 7(a) of Ding et al. (2003).
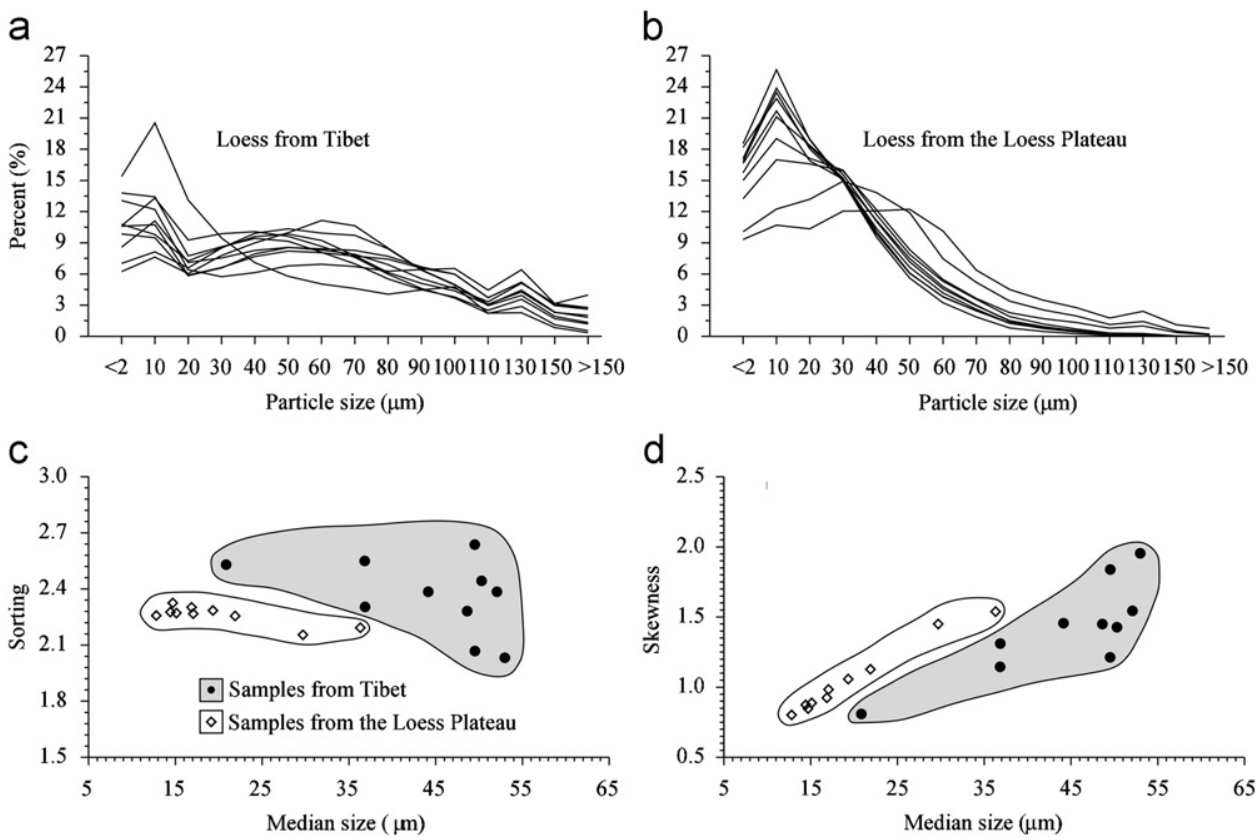

Fig. 13. Particle size distributions of loess in Tibet (a) and the Loess Plateau (b), and plots of median size against sorting (c) and skewness (d).

\section{Discussion}

\subsection{Provenance of the loess deposits in the southern Tibet}

Geochemical, mineralogical, and granulometric evidence from our study indicates that the source materials of the Tibetan loess are quite different from the eolian deposits on the Loess Plateau. A question that arises is: what is the source region of the sand dunes and loess in the interior of Tibet?

Field investigations indicate that there are fanglomerates and glacial moraines in the mountain valleys within the study area. These deposits can be transported downslope by meltwater, floods and sheet wash. Moreover, large alluvial fans also occur in the heavily braided river valley. Therefore, the deposits within the valley are rich in gravel, 
sand, silt and clay, providing the materials for both dunebuilding and loess accumulation.

The prevailing winds are west to southwest in the region studied, paralleling the Yarlung Zangbo River valley. This river valley has a deep "gorge-like" morphology along certain reaches of the drainage. This geomorphology produces a "Venturi effect" by converging air flow, and enhances strong winds and dust storms during the dry and windy seasons of spring and winter. Meteorological data show that strong winds, above a velocity of $17.2 \mathrm{~m} / \mathrm{s}$, can occur for 50-75 days per year (Tibetan Plateau Expedition of the Chinese Academy of Sciences, 1984). Wind sorting on the braided, sand and silt rich channels results in the loess accumulation on the foothills of the mountains along the middle reaches of the Yarlung Zangbo River.

The local source of the loess in the region studied can also be demonstrated by the particle size results. Based on the experiments in wind tunnels and studies of modern dust storms, Pye (1987) points out that only dust particles finer than $20 \mu \mathrm{m}$ can be transported in long-term suspension over a great altitudinal range and long distances. In contrast, particles in the size range of $20-70 \mu \mathrm{m}$ can be only transported in short-term suspension, and particles larger than $70 \mu \mathrm{m}$ can be only transported by saltation or modified saltation. The size fraction of particles larger than $20 \mu \mathrm{m}$ in Tibetan loess can be up to $80 \%$, suggesting most of the particles are transported in the manner of short-term suspension and/or saltation and for short distances, derived from the local river channel.

Our geochemical evidence also demonstrates that loess deposits from Tibet and the Chinese Loess Plateau have different provenances. By comparison with the geochemical compositions of potential source rocks, we propose that loess in the studied region of Tibet most likely is derived from felsic rocks in the Lhasa terrane, and we infer that glaciers in the high mountains have played an important role in loess genesis in this part of Tibet.

\subsection{Loess accumulation and its link with the last deglaciation in Tibet}

The OSL ages obtained for the typical loess deposits along the middle reaches of the Yarlung Zangbo River range between 13,000 and $2700 \mathrm{yr}$, indicating that loess in Tibet has accumulated since the last deglaciation. This raises two questions: (1) is loess sedimentation in southern Tibet a predominantly glacial or interglacial phenomenon? (2) why are loess deposits earlier than the last glacial maximum (LGM) rare or nonexistent? There is little question on the Chinese Loess Plateau that maximum loess deposition takes place during glacial periods and the earliest loess accumulation can be dated back to $2.58 \mathrm{Ma}$ (Liu, 1985). In addition, Thompson et al. (1989, 1997) report good evidence from two ice caps on Tibet that maximum dust flux took place during the LGM. How can maximum dust flux during the LGM in Tibet be reconciled with loess deposits of Lateglacial or post-glacial age?
There has long been a debate about LGM ice extent in Tibet. The hypothesis of a LGM ice sheet in Tibet (Kuhle, 1985, 1995) has been challenged by other studies (e.g., Zheng, 1989; Derbyshire et al., 1991; Shi, 1992; Lehmkuhl, 1998), which suggest that the LGM ice extent in the interior of Tibet was limited to glaciation of isolated mountain areas (Lehmkuhl, 1997, 1998).

Despite the debate about the spatial extent of the LGM ice in Tibet, LGM moraine deposits are widespread in Tibet, indicating remarkable LGM snowline depression (Tibetan Plateau Expedition of the Chinese Academy of Sciences, 1986; see also Lehmkuhl et al., 2000, their Fig. 2). There are good examples of these LGM moraines near our study area. On the eastern slopes of the mountains of Nyainqentanglha Shan, Owen et al. (2005) report cosmogenic radionuclide (CRN) age estimates of $\sim 52-71$, $\sim 19-21$, and $\sim 15-17 \mathrm{ka}$ for three sets of moraines that occur downvalley of modern glaciers. To the south of the Yarlung Zangbo River, three sets of moraines occur downvalley of the Qiangrong and Kaluxung glaciers. Owen et al. (2005) report CRN age estimates of $\sim 15-19, \sim 9-11$, and $\sim 2-3 \mathrm{ka}$ for these deposits. The elevation of the present snow line in the study region is $\sim 5800 \mathrm{~m}$ (Péwé et al., 1995), but the LGM snow line is estimated to have been $\sim 5200 \mathrm{~m}$ (Tibetan Plateau Expedition of the Chinese Academy of Sciences, 1986). Because the mountains along the two sides of the Yarlung Zangbo River valley range from 5000 to $6000 \mathrm{~m}$ above sea level, many of the mountain valleys and slopes were probably occupied by mountain glaciers and snow cover during the LGM (Fig. 14a; see also Lehmkuhl et al., 2000, their Fig. 5). From all these observations of glacial history, we infer that silt production by glacial grinding, frost weathering, and other highmountain geomorphic processes was almost certainly greater during the LGM compared to the Holocene. This leads us to infer that the lack of LGM loess in Tibet may not be a function of silt production, but instead be related to the ability of the landscape to trap and retain loess. If so, then the key to understanding the Tibetan loess record may lie in changing paleoenvironmental conditions and not silt supply alone.

Continuous paleoenvironmental records from Tibet are rare, and Gasse et al. (1996) have summarized the few records available. An $\sim 14,000$ cal-yr-long lacustrine record is available from Siling Co, to the north of the study area (Gu et al., 1993). Vegetation in this region is highmountain steppe, as is also the case in our study area, although the species composition differs somewhat (Hou, 1983). Hence, we consider this record to be at least an approximate picture of LGM-to-present paleoclimate in our study area. The paleoclimatic record from Siling Co is based on mineralogy and stable isotopes $(\mathrm{C}, \mathrm{O})$ in lacustrine carbonates. $\mathrm{Gu}$ et al. (1993) interpret the record to show: (1) cold and dry conditions from $\sim 14,000-11,500$ cal yr BP; (2) a rapid change to warmer and wetter conditions at $\sim 11,500-4700 \mathrm{cal} \mathrm{yr} B$, with maximum warmth, humidity and lake expansion from 


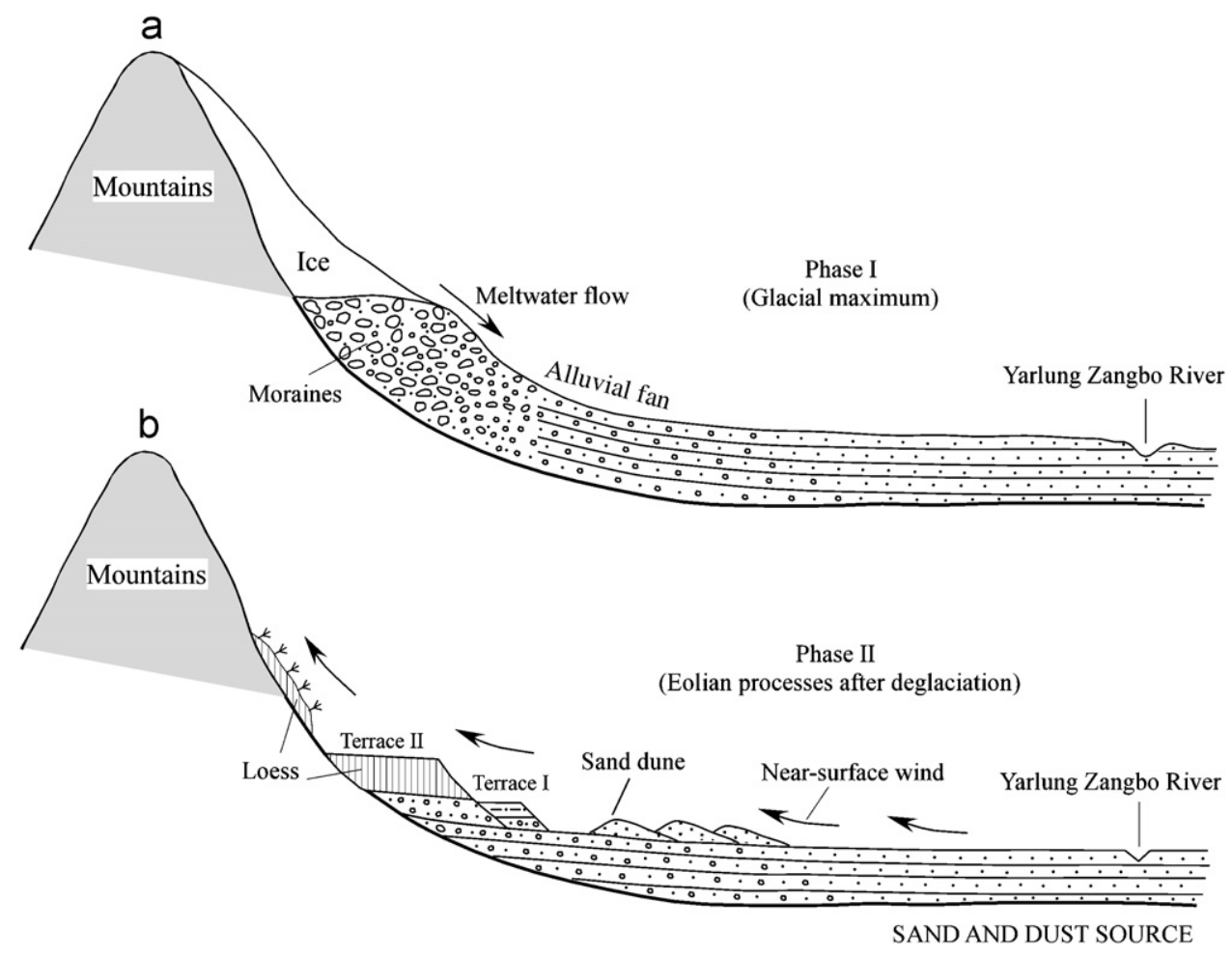

Fig. 14. Conceptual models showing the processes involved in the formation of loess in Tibet. (a) During a glacial maximum, the mountain slopes were mainly occupied by glaciers and moraines, and glacial deposits were reworked as outwash to the river valleys during the early stage of ice melting, discharging large amounts of clastic materials into the heavily braided river channel, (b) during interglacial time, particularly after most of the ice melted, wind sorting on the braided river channel resulted in sand dune building and loess accumulation on the windward slopes of the mountains.

$\sim 9500$ to $6300 \mathrm{cal} \mathrm{yr} \mathrm{BP}$, all due to a strengthening of monsoonal flow; and (3) dry conditions from $\sim 4700-3500$ and $\sim 2400-1300 \mathrm{cal}$ yr BP, alternating with moister periods. Farther to the northwest on the Tibetan Plateau, a lacustrine record of pollen and diatoms from Sumxi Co shows the same general sequence of events (Van Campo and Gasse, 1993), suggesting a similar forcing of regional climate controls (Gasse et al., 1996). Morrill et al. (2003) provide a synthesis of numerous records of the Asian monsoon, with a similar timing of events.

As the trapping of the dust by vegetation is a major part of the basis for loess accumulation, the cold, dry climate during the LGM may not have been favorable for vegetation growth and dust deposition. Even if there were loess deposits during the glacial maximum due to expanded glaciers and silt production, such deposits would be easily eroded off and recycled into river valleys during the early stage of deglaciation, when great volumes of ice melted (Fig. 14a). Actually, these processes must have been repeated many times during each glacial-interglacial cycle of the Quaternary. Therefore, even if loess deposits older than the LGM once existed, they could have been easily transported as outwash to river channels during the initial melting of the LGM ice. This hypothesis explains the lack of loess deposits older than $13,000 \mathrm{yr}$ in our study area. The only loess-like deposits probably older than the LGM (e.g., the site of TB10) are re-transported loess or soils.
The present loess in many parts of Tibet has accumulated mostly after the early stage of ice melting (Fig. 14b), and this process can be subdivided into two steps. First, a large volume of sediment must have been present as outwash in river channels in the early stage of the last deglaciation, and river valleys developed braided channels because of the excessive sediment loads. Second, wind sorting of glaciofluvial outwash deposits led to dune formation and loess accumulation during the later stage of the last deglaciation and the Holocene. In this sense, the Tibetan loess has a "glacial" origin.

If the paleoclimatic records of Siling Lake and Sumxi Lake, as reported by Gu et al. (1993) and Van Campo and Gasse (1993) are correct, retention of loess on hillslopes would not have taken place until there was an increase in monsoonal flow, with warmer temperatures, higher precipitation and humidity, and presumably greater vegetation cover. Based on the lacustrine records, this would have occurred around 11,500 cal yr BP, and explains why two of our loess sections have maximum-limiting OSL ages of $\sim 13,000-11,000$ cal yr BP. A similar interpretation was inferred by Muhs et al. (2003) for loess in central Alaska, USA, where it is thought that significant retention of loess may have required the arrival of boreal forest. Such an interpretation reconciles the lack of LGM loess in southern Tibet with the record of maximum dust accumulation in ice caps farther north on the Tibetan Plateau (Thompson et al., 1989, 1997). Dust flux onto an ice cap is the result 
primarily of silt supply because vegetation plays no role. Furthermore, we hypothesize that dust in these morenortherly Tibetan ice caps is derived from the deserts of northwestern China (for instance, the Taklimakan Desert) rather than from sources to the south. Although loess accumulation occurs in glacial time on the Loess Plateau, and maximum silt production in Tibet also occurs during this period, loess accumulation in the interior of Tibet may occur primarily in interglacial periods, when warmer temperatures, greater monsoon-derived precipitation, and greater vegetation cover occurs.

\section{Conclusions}

Sand dunes and loess deposits are widespread in the wide valleys along the middle reaches of the Yarlung Zangbo River. OSL dating indicates that the loess deposits have a basal age of 13,000-11,000 yr, suggesting they accumulated after the last deglaciation. Geochemical, mineralogical, and granulometric evidence indicates that the source materials of the Tibetan loess are quite different from eolian deposits on the Loess Plateau. The deposits appear to be locally derived, perhaps from granitic rocks to the north of the Yarlung Zangbo River, during the last glacial period, when glaciers expanded and production of silt-sized particles was enhanced. The particles were deflated from braided river channels by local, near-surface winds. Although silt production may have been at a maximum during the last glacial maximum, loess retention on hillslopes and terraces was minimal, due to a lack of stabilizing vegetation under cold, dry full-glacial conditions. However, during the deglacial period and early Holocene, increased monsoonal flow produced warmer, wetter conditions over the region. Such conditions would in turn have produced a greater vegetation cover that could have effectively trapped silt. The lack of full-glacial loess is either due to the poorvegetation cover under cold/dry and windy climatic conditions or due to the erosion of possible glacial loess by glaciofluvial outwash during the beginning of each interglacial. Such processes would have been repeated during each glacial-interglacial cycle of the Quaternary. Thus, the present loess in Tibet has accumulated since the last deglaciation.

\section{Acknowledgments}

This study was supported by the Project of KZCX2YW-130 from the Chinese Academy of Sciences and the National Basic Research Program of China (2004CB720202). Muhs' work is supported by the Earth Surface Dynamics Program of the US Geological Survey. We thank Paul Kapp for helpful discussions of bedrock geology and Kathleen Simmons, Robert Thompson, and two perceptive referees for helpful comments.

\section{References}

Aitchison, J.C., Badengzhu, Davis, A.M., Liu, J., Luo, H., Mapas, J., McDermid, I., Wu, H., Ziabrev, S.V., Zhou, M.-F., 2000. Remnants of a Cretaceous intra-oceanic subduction system within the YarlungZangbo suture (southern Tibet). Earth and Planetary Science Letters 183, 231-244.

Aitken, M.J., 1985. Thermoluminescence Dating. Academic Press, London, 359pp.

Aitken, M.J., 1998. An Introduction to Optical Dating. Oxford University Press, Oxford, 267pp.

Beswick, A.E., 1973. An experimental study of alkali met al distributions in feldspars and micas. Geochimica et Cosmochimica Acta 37, 183-208.

Bhatia, M.R., Crook, K.A.W., 1986. Trace element characteristics of graywackes and tectonic setting discrimination of sedimentary basins. Contributions to Mineralogy and Petrology 92, 181-193.

Biscaye, P.E., Grousset, F.E., Revel, M., Van der Gaast, S., Zielinski, G.A., Vaars, A., Kukla, G., 1997. Asian provenance of glacial dust (stage 2) in the Greenland Ice Sheet Project 2 Ice Core, Summit, Greenland. Journal of Geophysical Research 102, 26,765-26,781.

Debon, F., Le Fort, P., Sheppard, S.M.F., Sonet, J., 1986. The four plutonic belts of the Transhimalaya-Himalaya: a chemical, mineralogical, isotopic, and chronological synthesis along a Tibet-Nepal section. Journal of Petrology 27, 219-250.

Derbyshire, E., Shi, Y., Li, J., Zheng, B., Li, S., Wang, J., 1991. Quaternary glaciation of Tibet: the geological evidence. Quaternary Science Reviews 10, 485-510.

Derbyshire, E., Meng, X.M., Kemp, R.A., 1998. Provenance, transport and characteristics of modern eolian dust in western Gansu Province, China, and interpretation of the Quaternary loess record. Journal of Arid Environment 39, 497-516.

Ding, Z.L., Yu, Z.Y., Rutter, N.W., Liu, T.S., 1994. Towards an orbital time scale for Chinese loess deposits. Quaternary Science Reviews 13, $39-70$.

Ding, L., Kapp, P., Zhong, D., Deng, W., 2003. Cenozoic volcanism in Tibet: evidence for a transition from oceanic to continental subduction. Journal of Petrology 44, 1833-1865.

Dubois-Côté, V., Hébert, R., Dupuis, C., Wang, C.S., Li, Y.L., Dostal, J., 2005. Petrological and geochemical evidence for the origin of the Yarlung Zangbo ophiolites, southern Tibet. Chemical Geology 214, 265-286.

Dupuis, C., Hérbert, R., Dubois-Côté, V., Wang, C.S., Li, Y.L., Li, Z.J., 2005. Petrology and geochemistry of mafic rocks from mélange and flysch units adjacent to the Yarlung Zangbo Suture Zone, southern Tibet. Chemical Geology 214, 287-308.

Fang, X., Lü, L., Mason, J.A., Yang, S., An, Z., Li, J., 2003. Pedogenic response to millennial summer monsoon enhancements on the Tibetan Plateau. Quaternary International 106/107, 79-88.

Gallet, S., Jahn, B.M., Torii, M., 1996. Geochemical characterization of the Luochuan loess-paleosol sequence, China, and paleoclimatic implications. Chemical Geology 133, 67-88.

Gasse, F., Fontes, J.Ch., Van Campo, E., Wei, K., 1996. Holocene environmental changes in Bangong Co basin (Western Tibet), Part 4: discussion and conclusions. Palaeogeography, Palaeoclimatology, Palaeoecology 120, 79-92.

Graham, I.J., Ditchburn, R.G., Whitehead, N.E., 2001. Be isotope analysis of a 0-500 ka loess-paleosol sequence from Rangitatau East, New Zealand. Quaternary International 76/77, 29-42.

Gu, Z., Liu, J., Yuan, B., Liu, T., Liu, R., Liu, Y., Zhang, G., 1993. The changes in monsoon influence in the Qinghai-Tibetan Plateau during the past 12,000 years: geochemical evidence from the Lake Selin sediments. Chinese Science Bulletin 38, 61-64.

Harrison, T.M., Yin, A., Grove, M., Lovera, O.M., Ryerson, F.J., Zhou, X., 2000. The Zedong window: a record of superposed Tertiary convergence in southeastern Tibet. Journal of Geophysical Research $105,19,211-19,230$. 
Heier, K.S., Billings, G.K., 1970. Rubidium. In: Wedepohl, K.H. (Ed.), Handbook of Geochemistry. Springer, Berlin, pp. 37B1-37N1.

Heller, F., Liu, T.S., 1984. Magnetism of Chinese loess deposits. Geophysical Journal of the Royal Astronomical Society 77, 125-141.

Hou, H.Y., 1983. Vegetation of China with reference to its geographical distribution. Annals of the Missouri Botanical Garden 70, 509-548.

Hövermann, J., 1987. Morphogenetic regions in northeast Xizang (Tibet). In: Hövermann, J., Wenying, W. (Eds.), Reports of the QinghaiXizang (Tibet) Plateau. Science Press, Beijing, pp. 112-139.

Jahn, B.M., Gallet, S., Han, J.M., 2001. Geochemistry of the Xining, Xifeng and Jixian sections, Loess Plateau of China: eolian dust provenance and paleosol evolution during the last $140 \mathrm{ka}$. Chemical Geology 178, 71-94.

Kapp, J.L., Harrison, T.M., Kapp, P., Grove, M., Lovera, O.M., Lin, D., 2005. Nyainqentanglha Shan: a window into the tectonic, thermal, and geochemical evolution of the Lhasa block, southern Tibet. Journal of Geophysical Research 110.

Kuhle, M., 1985. Glaciation research in the Himalayas: a new ice age theory. Universitas 27, 281-294.

Kukla, G., 1987. Loess stratigraphy in central China. Quaternary Science Reviews 6, 191-219.

Kuhle, M., 1995. Glacial isostatic uplift of Tibet as a consequence of a former ice sheet. GeoJournal 37, 431-449.

Küster, Y., Hetzel, R., Krbetschek, M., Tao, M.X., 2006. Holocene loess sedimentation along the Qilian Shan (China): significance for understanding the processes and timing of loess deposition. Earth and Planetary Science Letters 25, 114-125.

Lehmkuhl, F., 1997. The spatial distribution of loess and loess-like sediments in the mountain areas of Central and High Asia. Zeitschrift für Geomorphologie, Supplementband 111, 97-116.

Lehmkuhl, F., 1998. Extent and spatial distribution of Pleistocene glaciations in eastern Tibet. Quaternary International 45/46, 123-134.

Lehmkuhl, F., Owen, L.A., 2005. Late Quaternary glaciation of Tibet and the bordering mountains: a review. Boreas 34, 87-100.

Lehmkuhl, F., Klinge, M., Rees-Jones, J., Rhodes, E.J., 2000. Late Quaternary eolian sedimentation in central and south-eastern Tibet. Quaternary International 68/71, 117-132.

Li, C., Ma, H.Z., 1996. Loess in Xining. Qinghai Geology 2, 1-10.

Liu, T.S., 1985. Loess and the Environment. China Ocean Press, Beijing, $251 \mathrm{pp}$.

Liu, C.Q., Masuda, A., Okada, A., Yabuki, S., Zhang, J., Fan, Z.L., 1993. A geochemical study of loess and desert sand in northern China: implications for continental crust weathering and composition. Chemical Geology 196, 359-374.

Lu, H.Y., Wang, X.Y., An, Z.S., Miao, X.D., Zhu, R.X., Ma, H.Z., Li, Z., Tan, H.B., Wang, X.Y., 2004. Geomorphologic evidence of phased uplift of the northeastern Qinghai-Tibet Plateau since 14 million years ago. Science in China (Series D) 47, 822-833.

Markey, B.G., Bøtter-Jensen, L., Duller, G.A.T., 1997. A new flexible system for measuring thermally and optically stimulated luminescence. Radiation Measurements 27, 83-90.

McLennan, S.M., 1989. Rare earth elements in sedimentary rocks: influence of provenance and sedimentary processes. Reviews in Mineralogy and Geochemistry 21, 169-200.

Morrill, C., Overpeck, J.T., Cole, J.E., 2003. A synthesis of abrupt changes in the Asian summer monsoon since the last deglaciation. The Holocene 13, 465-476.

Muhs, D.R., Budahn, J.R., 2006. Geochemical evidence for the origin of late Quaternary loess in central Alaska. Canadian Journal of Earth Sciences 43, 323-337.

Muhs, D.R., Stafford Jr., T.W., Cowherd, S.D., Mahan, S.A., Kihl, R., Maat, P.B., Bush, C.A., Nehring, J., 1996. Origin of the late Quaternary dune fields of northeastern Colorado. Geomorphology 17, 129-149.

Muhs, D.R., Ager, T.A., Bettis III, E.A., McGeehin, J., Been, J.M., Begét, J.E., Pavich, M.J., Stafford Jr., T.W., Stevens, D.S.P., 2003. Stratigraphy and paleoclimatic significance of late Quaternary loess- paleosol sequences of the Last Interglacial-glacial cycle in central Alaska. Quaternary Science Reviews 22, 1947-1986.

Murray, A.S., Wintle, A.G., 2000. Luminescence dating of quartz using an improved single-aliquot regenerative-dose protocol. Radiation Measurements $32,57-73$.

Obruchev, V.A., 1911. The question of the origin of loess-in defence of the eolian hypothesis. Izvêstiya Tomskago Tekhnologicheskago Instituta $33,38$.

Olivarez, A.M., Owen, R.M., Rea, D.K., 1991. Geochemistry of eolian dust in Pacific pelagic sediments: implications for paleoclimatic interpretations. Geochimica et Cosmochimica Acta 55, 2147-2158

Owen, L.A., Finkel, R.C., Barnard, P.L., Ma, H.Z., Asahi, K., Caffee, M.W., Derbyshire, E., 2005. Climatic and topographic controls on the style and timing of late Quaternary glaciation throughout Tibet and the Himalaya defined by ${ }^{10} \mathrm{Be}$ cosmogenic radionuclide surface exposure dating. Quaternary Science Reviews 24, 1391-1411.

Owen, L.A., Finkel, R.C., Ma, H.Z., Barnard, P.L., 2006. Late Quaternary landscape evolution in the Kunlun Mountains and Qaidam Basin, Northern Tibet: a framework for examining the links between glaciation, lake level changes and alluvial fan formation. Quaternary International 154/155, 73-86.

Péwé, T.L., Liu, T., Slatt, R.M., 1987. Retransported loess in the southern part of the Qinghai-Xizang (Tibet) Plateau, China. In: Liu, T.S. (Ed.), Aspects of Loess Research. China Ocean Press, Beijing, pp. 70-75.

Péwé, T.L., Liu, T.S., Slatt, R.M., Li, B.Y., 1995. Origin and character of loesslike silt in the southern Qinghai-Xizang (Tibet) Plateau, China. US Geological Survey Professional Paper 1549, 1-55.

Prescott, J.R., Hutton, J.T., 1994. Cosmic ray contributions to dose rates for luminescence and ESR dating: large depths and long-term time variations. Radiation Measurements 23, 497-500.

Pye, K., 1987. Eolian Dust and Dust Deposits. Academic Press, London, 334pp.

Richthofen, F., 1882. On the mode of origin of the loess. Geological Magazine 9, 283-305.

Rost, K.L., 2000. Pleistocene paleoenvironmental changes in the high mountain ranges of central China and adjacent regions. Quaternary International 65/66, 147-160.

Shi, Y., 1992. Glaciers and glacial geomorphology in China. Zeitschrift für Geomorphologie, Supplementband 86, 51-63.

Sino-UK Geological Expedition Team, 1990. Geological Evolution in the Tibetan Plateau. Science Press, Beijing, 415pp.

Smalley, I.J., 1966. The properties of glacial loess and formation of loess deposits. Journal of Sedimentary Petrology 36, 669-676.

Smalley, I.J., 1990. Possible formation mechanisms for the modal coarsesilt quartz particles in loess deposits. Quaternary International 7/8, 23-28.

Smalley, I.J., 1995. Making the material: the formation of silt-sized primary mineral particles for loess deposits. Quaternary Science Reviews 14, 645-651.

Smalley, I.J., Vita-Finzi, C., 1968. The formation of fine particles in sand deserts and the nature of "desert" loess. Journal of Sedimentary Petrology 38, 766-774.

Sun, J.M., 2002a. Provenance and forming mechanisms of the loess sediments on the high mountain regions of northwestern China. Quaternary Research 58, 341-351.

Sun, J.M., 2002b. Provenance of loess material and formation of loess deposits on the Chinese Loess Plateau. Earth and Planetary Science Letters 203, 845-859.

Sun, J.M., Liu, T.S., Lei, Z.F., 2000. Sources of heavy dust fall in Beijing, China on April 16, 1998. Geophysical Research Letters 27, 2105-2108.

Sun, J.M., Zhang, M.Y., Liu, T.S., 2001. Spatial and temporal characteristics of dust storms in China and its surrounding regions, 1960-1999: relations to source area and climate. Journal of Geophysical Research (D-series) 106, 10,325-10,334. 
Taylor, S.R., McLennan, S.M., 1985. The Continental Crust: its Composition and Evolution. Blackwell, Oxford, 312pp.

Taylor, S.R., McLennan, S.M., McCulloch, M.T., 1983. Geochemistry of loess, continental crustal composition and crustal model ages. Geochimica et Cosmochimica Acta 47, 1897-1905.

Thompson, L.G., Mosley-Thompson, E., Davis, M.E., Bolzan, J.F., Dai, J., Yao, T., Gundestrup, N., Wu, X., Klein, L., Xie, Z., 1989. Holocene-Late Pleistocene climatic ice core records from QinghaiTibetan Plateau. Science 246, 474-477.

Thompson, L.G., Yao, T., Davis, M.E., Henderson, K.A., MosleyThompson, E., Lin, P.-N., Beer, J., Synal, H.-A., Cole-Dai, J., Bolzan, J.F., 1997. Tropical climate instability: the last glacial cycle from a Qinghai-Tibetan ice core. Science 276, 1821-1825.

Tibetan Plateau Expedition of the Chinese Academy of Sciences, 1984. Climate of Tibet. Science Press, Beijing, 300pp.

Tibetan Plateau Expedition of the Chinese Academy of Sciences, 1986. Glaciers in Tibet. Science Press, Beijing, 328pp.

Van Campo, E., Gasse, F., 1993. Pollen- and diatom-inferred climatic and hydrological changes in Sumxi Co basin (western Tibet) since 13,000 yr B.P. Quaternary Research 39, 300-313.

Wang, X.Y., Lu, H.Y., Li, Z., Deng, C.L., Tan, H.B., Song, Y.G., 2003. Paleoclimatic significance of mineral magnetic properties of loess sediments in Northeastern Qinghai-Tibetan Plateau. Chinese Science Bulletin 48, 2126-2133.

Wright, J.S., 2001. "Desert" loess versus "glacial" loess: quartz silt formation, source areas and sediment pathways in the formation of loess deposits. Geomorphology 36, 231-256.

Yang, S.L., Ding, Z.L., 2004. Comparison of particle size characteristics of the Tertiary 'red clay' and Pleistocene loess in the Chinese Loess Plateau: implications for origin and sources of the 'red clay'. Sedimentology 51, 77-93.

Yin, A., Harrison, T.M., 2000. Geologic evolution of the HimalayanTibetan orogen. Annual Reviews of Earth and Planetary Science 28, 211-280.

Zhang, K.J., 2004. Secular geochemical variations of the Lower Cretaceous siliciclastic rocks from central Tibet (China) indicate a tectonic transition from continental collision to back-arc rifting. Earth Planetary Science Letters 229, 73-89.

Zhang, X.Y., Arimoto, R., Cao, J.J., An, Z.S., Wang, D., 2001. Atmospheric dust aerosol over the Tibetan Plateau. Journal of Geophysical Research 106, 18,471-18,476.

Zheng, B., 1989. Controversy regarding the existence of a large ice sheet on the Qinghai-Xizang (Tibetan) Plateau during the Quaternary Period. Quaternary Research 32, 121-123. 